\title{
Article
}

\section{Legal Pathways to Coal Phase-Out in Italy in 2025}

\author{
Matteo Fermeglia ${ }^{1, *}\left(\mathbb{D}\right.$, Paolo Bevilacqua ${ }^{2}\left(0\right.$, Claudia Cafaro $^{3}$, Paolo Ceci $^{3}(\mathbb{D}$ and \\ Antonio Fardelli ${ }^{3}$ \\ 1 Faculty of Law, Hasselt University, Martelarenlaan 42, 3500 Hasselt, Belgium \\ 2 Department of Architecture and Engineering, University of Trieste, Via Alfonso Valerio 6/a, 34127 Trieste, \\ Italy; paolo.bevilacqua@dia.units.it \\ 3 Institute of Atmospheric Pollution Research (IIA)-National Research Council (CNR) of Italy, \\ Via Salaria Km 29300 Postal Box 10, 00015 Monterotondo, Italy; cafaro@iia.cnr.it (C.C.); ceci@iia.cnr.it (P.C.); \\ fardelli@iia.cnr.it (A.F.) \\ * Correspondence: matteo.fermeglia@uhasselt.be
}

Received: 3 September 2020; Accepted: 21 October 2020; Published: 27 October 2020

check for updates

\begin{abstract}
This contribution aims to provide an in-depth outlook of the phase-out of coal-fired energy generation in Italy. In particular, this article analyzes the state-of-the-art with regard to both the current role of coal generation and the performance of the main legal and regulatory tools as implemented in Italy thus far to ensure the closure of all coal power plants by 2025 as announced in the Italian National Climate and Energy Plan. Based on existing data and scenarios on both electricity production and demand trends, this article unfolds the marginal role played by coal-fired generation in the Italian energy mix. In addition, this paper aims to highlight the outstanding technical uncertainties and regulatory hurdles in the way towards de-carbonization of energy generation in Italy. This paper argues that several remarkable improvements are needed in order to avoid over-generation (especially through natural gas), to upscale the penetration of renewable energy sources, and develop the necessary infrastructures to adequately deliver on the full phasing-out of coal within the expected timeframes.
\end{abstract}

Keywords: de-carbonization; coal-fired generation; coal phase-out; energy regulation

\section{Introduction}

The need for an abrupt transition away from fossil fuels in light of the climate crisis and the uprising of greenhouse gases (GHG) emissions worldwide has arguably been championed in light of the EU's need to ensure climate neutrality in 2050 [1]. To this end, the phase-out of coal-fired power plants as a conventional energy source is one of the utmost compelling issues arising at different latitudes as the business [2], socio-economic [3], environmental [4], and net-energy [5] cases for such an energy source are rapidly losing ground.

The phasing out of coal as a highly GHG-emitting energy source strikes exactly at the core of two pivotal policy objectives of the EU, i.e., environmental and climate protection and energy security pursuant to articles 191, 192, and 194 of the Treaty of Functioning of the EU (TFEU). Yet the ultimate regulation of energy generation mixes lies outside the EU's competences on energy matters, as it expressly falls within the scope of the so-called sovereignty clause under article 194(2) TFEU. Therefore, the ultimate decision as to the shutdown of coal power plants remains firmly in the hands of EU member states. Thus far, 21 member states have either already phased out coal-fired generation (Estonia, Latvia, Lithuania, Belgium, Malta, Luxembourg, Cyprus), or have committed to do so within specific timeframes [6]. Altogether, such commitments would lead to a decrease in the use of coal by $70 \%$ by 2030 compared to 2015 [6]. 
To deliver on such commitments, however, member states must tackle at least four compelling issues. First, energy transmission and distribution networks must be enhanced, in order to ensure full integration of renewable energy sources (RES) into the grid. Second, base-load capacity must be ensured, in order to prevent energy outages and avoid over-generation. Third, adequate energy price signals must be provided for, in order to drive the required investments in breakthrough technologies for GHG emissions reduction (most importantly, energy storage and demand resources). Fourth, yet not less important, a predictable regulatory environment must be established, in order to fend off claims for financial compensation by operators of coal-fired power plants in light of the creation of stranded assets [7].

Against this backdrop, Italy has set for an overtly ambitious policy on total phase-out of coal power generation by 2025. This policy is clearly spelt out in the National Energy and Climate Plan (NECP), submitted and assessed by the European Commission in 2019 pursuant to the Energy Union Governance Regulation (No. 2018/1999/EU) [8]. Italy has taken far-reaching steps to gradually sidetrack coal power generation within its energy mix while fostering RES generation and increasingly relying on natural gas generation to ensure base-load and peak generation [9]. Nonetheless, the regulatory and legal measures deployed to ensure the closure of coal power plants may unfold several shortcomings in order to perform consistently with the mid-to-long term policy objectives and trajectories in terms of de-carbonization of the energy sector as enshrined in the NECP.

This paper hence aims to chart the implementation of the recent regulatory tools deployed in Italy against the need to achieve the key policy objective of full coal phase-out. Previous works have addressed EU—scale implications to duly offset for coal phase-out [10], while others have extensively compared different pathways for phase-out in Italy and other EU member states [11], also in the context of long-term full de-carbonization of the energy sector [12]. Conversely, this article will unfold and draw lessons from the hurdles and pitfalls arisen in the context of policy implementation for the phase-out of coal-fired generation in Italy. These elements ought to be adequately taken into account while shaping regulatory approaches to safeguard security of supply, avoid over-reliance on other conventional fossil fuels in the energy mix (such as natural gas), and bolster uptake of RES consistently with—and ideally beyond - the binding targets embedded in the overarching EU 2030 Energy and Climate governance framework [13]. It will achieve this purpose by reviewing available data and information on the trajectories and state-of-the-art with regard to coal-fired generation, as well as on the existing body of literature on energy policy and regulation.

This article is structured as follows. Section 2 briefly explains the main methodological underpinnings of the work. Section 3 provides an overview of the Italian coal-fired energy generation and summarizes the key policy objectives with regard to the coal phase-out. Section 4 takes stock of the current regulatory and legal tools deployed to deliver on the above key policy objectives with a view to provide a snapshot of their performance. In particular, this section analyzes the performance of the following legal and regulatory tools: The capacity mechanism; the RES auctions, the long-term power purchase agreements (PPAs) for RES projects, and the permitting procedures for energy infrastructures. Section 5 critically appraises the findings in the previous sections and concludes.

\section{Methodology}

This paper draws from desk-based analysis of data and literature. In order to identify and highlight the key elements to define the functional trajectories and steps to the achievement of the Italian de-carbonization mid- and long-term policy objectives, we have collected and reviewed relevant information from available national and international reports, as well as energy law and policy literature to address the following issues:

- The current state-of-the-art of the use of coal-fired generation for electricity in Italy, as reported from international official national sources;

- The main outcomes of the first implementation of the capacity mechanism, the RES auctions and the PPAs; 
- The advancement of the permitting procedures with regard to the relevant energy infrastructures in the context of the NECP.

This information and data have been hence adequately processed, refined, and assessed against the key scenarios developed in the Italian NECP, with particular focus on the role of natural gas as a transitional energy source towards the full uptake of RES generation.

\section{De-Carbonization of the Energy Sector and Coal-Phase Out: The Italian Context}

\subsection{The Evolution of the Italian Energy Mix and Italian Energy Policy}

Italy's energy mix has progressively evolved in the direction of fostering RES generation while steadily reducing coal-fired generation. Such a trend has been mainly driven by the developments in Italy's energy policy, especially in the wake of the adoption of the first comprehensive National Energy Strategy (NES) in 2013. Table 1 and Figure 1 below display the evolution of Italy's energy mix from 1990 to 2018. These data show a steadfast decline of coal-fired generation in Italy's energy mix, with a rapid decreasing trend over the last 5 years-plummeting from $16.8 \%$ in 2013, $11.9 \%$ in 2017, and $10.7 \%$ in $2018(-6.1 \%)$. Notwithstanding this, Italy's overall electricity production has followed a rather linear incremental path, essentially due to the substantial increase in natural gas and RES (most prominently, wind and solar).

Table 1. Italian electricity production by source [14].

\begin{tabular}{|c|c|c|c|c|c|c|c|c|c|}
\hline & & 1990 & 2000 & 2010 & 2011 & 2013 & 2015 & 2017 & 2018 \\
\hline \multirow{2}{*}{ Total } & TWh & 218.59 & 275.30 & 301.19 & 301.61 & 289.06 & 282.39 & 295.79 & 289.12 \\
\hline & $\%$ & $100 \%$ & $100 \%$ & $100 \%$ & $100 \%$ & $100 \%$ & $100 \%$ & $100 \%$ & $100 \%$ \\
\hline \multirow{2}{*}{ Fossil Fuel } & TWh & 180.19 & 217.76 & 218.78 & 214.58 & 172.85 & 169.63 & 186.98 & 170.53 \\
\hline & $\%$ & 82 & 79 & 73 & 71 & 60 & 60 & 63 & 59 \\
\hline \multirow{2}{*}{ Coal } & TWh & 37.76 & 30.52 & 44.43 & 50.14 & 48.49 & 45.39 & 35.10 & 30.96 \\
\hline & $\%$ & 17.27 & 11.09 & 14.75 & 16.62 & 16.78 & 16.07 & 11.87 & 10.71 \\
\hline \multirow{2}{*}{$\begin{array}{l}\text { Natural } \\
\text { Gas }\end{array}$} & TWh & 39.71 & 101.36 & 152.74 & 144.55 & 108.88 & 110.86 & 140.35 & 128.54 \\
\hline & $\%$ & 18.17 & 36.82 & 50.71 & 47.93 & 37.67 & 39.26 & 47.45 & 44.46 \\
\hline \multirow{2}{*}{ Oil } & TWh & 102.72 & 85.88 & 21.71 & 19.89 & 15.48 & 13.38 & 11.53 & 11.03 \\
\hline & $\%$ & 46.99 & 31.20 & 7.21 & 6.59 & 5.36 & 4.74 & 3.90 & 3.82 \\
\hline \multirow{2}{*}{ Nuclear } & TWh & 0 & 0 & 0 & 0 & 0 & 0 & 0 & 0 \\
\hline & $\%$ & 0 & 0 & 0 & 0 & 0 & 0 & 0 & 0 \\
\hline Total & TWh & 38.40 & 57.54 & 82.41 & 87.03 & 116.21 & 112.76 & 108.81 & 118.59 \\
\hline Renewables & $\%$ & 18 & 21 & 27 & 29 & 40 & 40 & 37 & 41 \\
\hline \multirow{2}{*}{ Hydro } & TWh & 35.08 & 50.90 & 54.41 & 47.58 & 54.67 & 46.97 & 38.03 & 50.50 \\
\hline & $\%$ & 16.05 & 18.49 & 18.07 & 15.78 & 18.91 & 16.63 & 12.95 & 17.47 \\
\hline \multirow[b]{2}{*}{ Biofuels } & TWh & 0.01 & 0.99 & 7.39 & 8.63 & 14.89 & 17.05 & 17.00 & 16.78 \\
\hline & $\%$ & 0 & 0.36 & 2.45 & 2.86 & 5.15 & 6.04 & 5.75 & 5.80 \\
\hline \multirow{2}{*}{ Waste } & TWh & 0.09 & 0.92 & 4.19 & 4.51 & 4.50 & 4.77 & 4.86 & 4.83 \\
\hline & $\%$ & 0.04 & 0.33 & 1.39 & 1.50 & 1.56 & 1.69 & 1.64 & 1.67 \\
\hline \multirow{2}{*}{ Geothermal } & TWh & 3.22 & 4.71 & 5.38 & 5.65 & 5.66 & 6.19 & 6.20 & 6.11 \\
\hline & $\%$ & 1.47 & 1.71 & 1.79 & 1.87 & 1.56 & 2.19 & 2.10 & 2.11 \\
\hline \multirow{2}{*}{ Solar PV } & TWh & 0 & 0.02 & 1.91 & 10.80 & 21.59 & 22.94 & 24.98 & 22.65 \\
\hline & $\%$ & 0 & 0.01 & 0.63 & 3.58 & 7.47 & 8.12 & 8.45 & 7.83 \\
\hline Solar & TWh & 0 & 0 & 0 & 0 & 0 & 0 & 0 & 0 \\
\hline Thermal & $\%$ & 0 & 0 & 0 & 0 & 0 & 0 & 0 & 0 \\
\hline \multirow{2}{*}{ Wind } & TWh & 0 & 0.56 & 9.13 & 9.86 & 14.90 & 14.84 & 17.74 & 17.72 \\
\hline & $\%$ & 0 & 0.20 & 3.03 & 3.27 & 5.15 & 5.26 & 6.00 & 6.13 \\
\hline
\end{tabular}




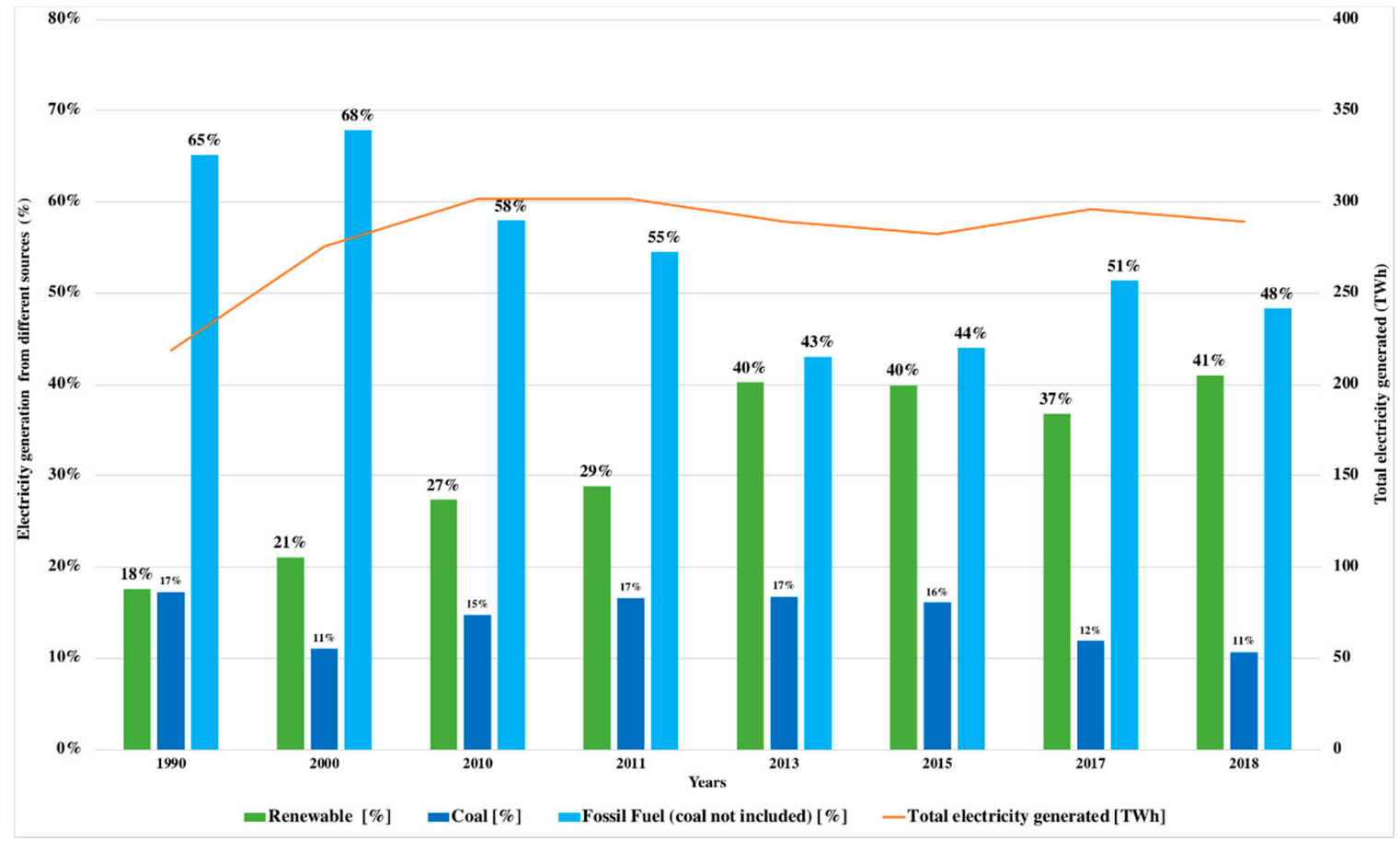

Figure 1. Evolution of Italy's energy mix [14].

Coal-fired generation in Italy currently consists of 8 operating power plants, contributing to $8.3 \mathrm{GW}$ electrical generation capacity (see Table 2). Coal-fired generation thus amounts to approximately $10-12 \%$ of the total Italian energy generation mix (see Table 1 and Figure 1).

Table 2. Existing Italian coal-fired combustion plants capacity [15].

\begin{tabular}{ccc}
\hline $\begin{array}{c}\text { Coal-Fired } \\
\text { Combustion Plant }\end{array}$ & $\begin{array}{c}\text { Thermal Capacity } \\
\text { (MWt) }\end{array}$ & $\begin{array}{c}\text { Electrical Capacity } \\
\text { (MWe) }\end{array}$ \\
\hline Torrevaldaliga Nord & 4260 & 1980 \\
Civitavecchia (RM) & 6560 & 2640 \\
Brindisi & 851 & 336 \\
Monfalcone (GO) & 2431 & 976 \\
Fusina & 200 & 72 \\
Porto Marghera (Venice) & 1540 & 600 \\
Lamarmora (Brescia) & 1470 & 700 \\
La Spezia & 1600 & 960 \\
Sulcis, Portoscuso (SU) & 18912 & 8264 \\
Fiume Santo (SS) & & \\
Total Installed Capacity & &
\end{tabular}

In Italy, coal-fired generation also plays quite a marginal role as compared to the overall coal-fired electricity generation EU-wide (including UK), as displayed in Figure 2 below. 


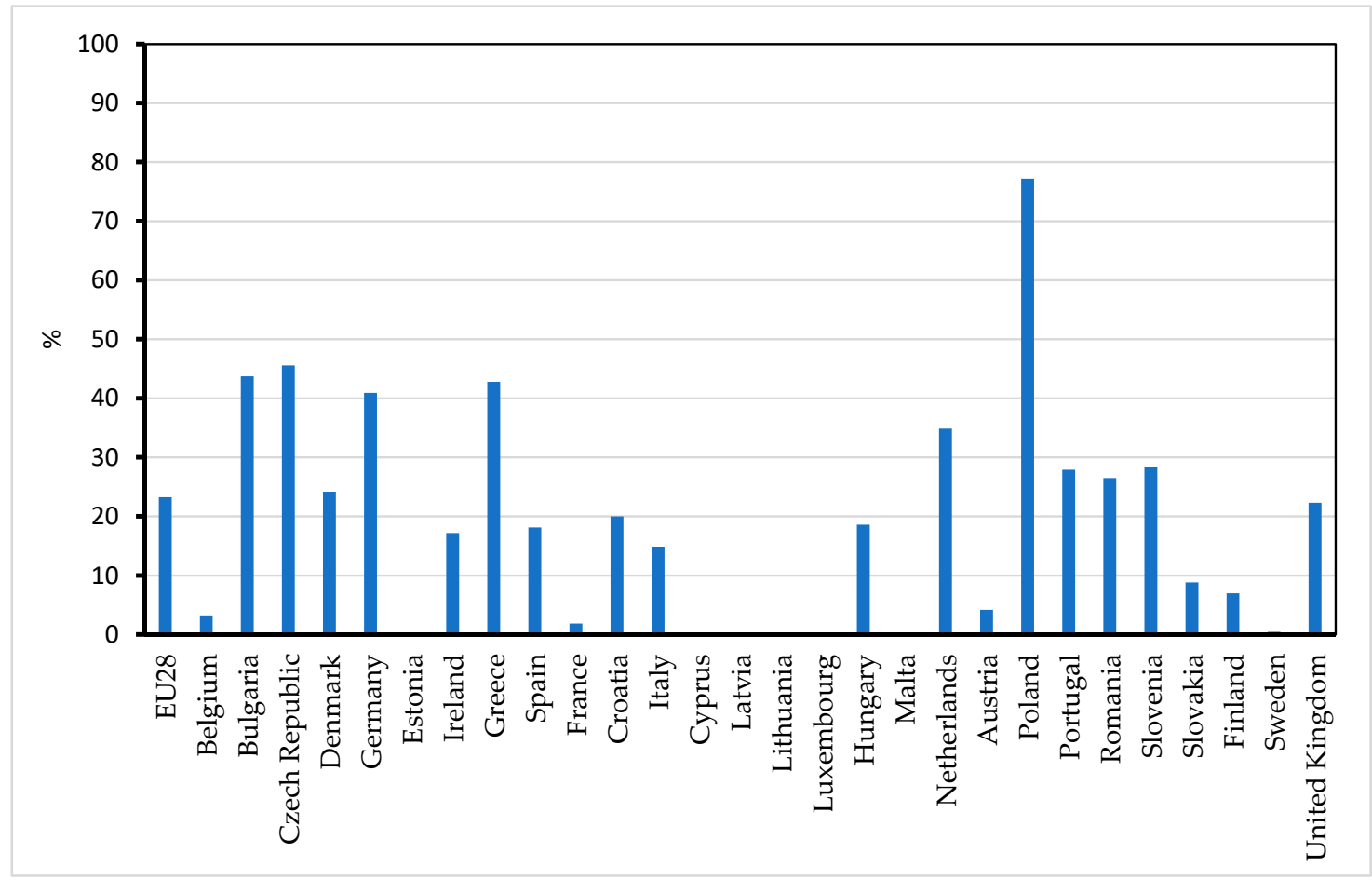

Figure 2. Share of electricity generation from coal and lignite in total electricity generation, EU-28 [16].

In the last 5 years, out of the above approximate $8 \mathrm{GW}$ coal-fired generation capacity, the actual generation has been increasingly reduced as it is now used only to cope with peak demand and partly to ensure the base-load of electricity. Importantly, moreover, while the overall coal generation capacity has remained unchanged, there has been a noticeable decrease in coal power plants' operation, as shown in Table 3 below.

Table 3. Italian coal-fired combustion plants operation (2014-2018) [15].

\begin{tabular}{ccccccc}
\hline Coal-Fired & Power Generation & \multicolumn{5}{c}{ Operating Hours } \\
Combustion Plant & Unit & $\mathbf{2 0 1 4}$ & $\mathbf{2 0 1 5}$ & $\mathbf{2 0 1 6}$ & $\mathbf{2 0 1 7}$ & $\mathbf{2 0 1 8}$ \\
\hline \multirow{2}{*}{ Torrevaldaliga Nord } & TN2 1420 MWt & 6867 & n/a & 6484 & 6791 & 5353 \\
Civitavecchia (RM) & TN3 1420 MWt & 6944 & n/a & 6195 & 5344 & 4676 \\
& TN4 1420 MWt & 6389 & n/a & 6001 & 5941 & 4367 \\
& GR1 1640 MWt & 5880 & 6330 & 5031 & 5173 & 4132 \\
Brindisi & GR2 1640 MWt & 7136 & 7620 & 3392 & 4798 & 4682 \\
& GR3 1640 MWt & 7616 & 7988 & 6276 & 4874 & 4152 \\
& GR4 1640 MWt & 7223 & 7891 & 6669 & 3412 & 3924 \\
Monfalcone (GO) & GR1 418 MWt & 6303 & n/a & 7619 & 7390 & 6062 \\
& GR2 433 MWt & 6693 & n/a & 7794 & 6230 & 7118 \\
& GR1 415.2 MWt & 6809 & 7762 & n/a & n/a & n/a \\
Fusina Porto Marghera & GR2 430.8 MWt & 6625 & 8192 & n/a & n/a & n/a \\
(Venice) & GR3 792.8 MWt & 6638 & 7479 & n/a & n/a & n/a \\
& (co-combust. coal/CSS) & - & - & - & - & - \\
& GR4 792.8 MWt & 7586 & 8153 & n/a & n/a & n/a \\
Lamarmora & (co-combust. coal/CSS) & - & - & - & - & - \\
(Brescia) & GR3 200 MWt & 3421 & 3537 & 3516 & 3384 & 3330 \\
La Spezia & SP3 1540 MWt & 6425 & 5740 & 6803 & 5057 & n/a \\
Sulcis Portoscuso (SU) & SU2 800 MWt & 6196 & n/a & 3511 & 5221 & 4142 \\
Fiume Santo (SS) & SU3 670 MWt & 5011 & n/a & 1469 & 2601 & 3437 \\
& GR3 800 MWt & 7597 & 4939 & 6618 & 7105 & 6147 \\
& GR4 800 MWt & 7116 & 5273 & 4454 & 8034 & 7564 \\
\hline
\end{tabular}


As shown in Table 1 above, the overall coal-fired generated energy in Italy in 2017 amounted to approximately $35 \mathrm{TWh}$. By adequately factoring this data with the coal 2017 GHG emission factor (equal to $870 \mathrm{~g} \mathrm{CO}_{2} / \mathrm{kWh}$ ), the GHG impact of coal generation in Italy totals $30,450 \mathrm{Gg} \mathrm{CO}_{2} /$ year. GHG emissions from the energy sector in Italy in 2017 equals around $104205 \mathrm{Gg} \mathrm{CO}_{2}$ eq; therefore, coal combustion accounts for approximately $30 \%$ of Italy's $\mathrm{CO}_{2}$ emissions in the energy sector [17].

We have disaggregated the same values in terms of each operating coal power plant breakdown as displayed in Table 4 below (as stated by operators). The GHG emissions trajectories for coal power plants shows a steady decrease, mostly due to the progressive under-reliance on coal generation (see also Table 3 above) and replacement of coal-fired generation with other energy sources-mostly natural gas and RES.

Table 4. Total carbon dioxide equivalent emissions $\left(\mathrm{Gg} \mathrm{CO}_{2} \mathrm{eq}\right)$ from coal-fired combustion plant in Italy (2014-2018).

\begin{tabular}{cccccc}
\hline $\begin{array}{c}\text { Coal-Fired } \\
\text { Combustion Plant }\end{array}$ & $\mathbf{2 0 1 4}$ & $\mathbf{2 0 1 5}$ & $\mathbf{2 0 1 6}$ & $\mathbf{2 0 1 7}$ & $\mathbf{2 0 1 8}$ \\
\hline Torrevaldaliga Nord Civitavecchia (RM) & $10,892.368$ & $10,736.213$ & $10,181.950$ & 9747.838 & 8081.026 \\
Brindisi & $11,972.979$ & $13,115.643$ & 8275.345 & 6485.120 & 5477.190 \\
Monfalcone (GO) & 1775.700 & 2037.300 & 2145.200 & 1920.400 & 1876.600 \\
Fusina & 4838.368 & 5779.412 & 4665.440 & 3682.847 & 3556.557 \\
Porto Marghera (Venice) & 193.653 & 219.311 & 204.505 & 212.964 & 205.652 \\
Lamarmora (Brescia) & 2741.860 & 2532.872 & 2831.877 & 2019.990 & 1928.640 \\
La Spezia & 1648.011 & 1294.928 & 679.581 & 1074.077 & 1001.932 \\
Sulcis, Portoscuso (SU) & 3188.000 & 2404.000 & 2535.000 & 3514.000 & 3160.000 \\
Fiume Santo (SS) & $37,250.939$ & $38,119.679$ & $31,518.898$ & $28,657.236$ & $25,287.597$ \\
Total & & & & &
\end{tabular}

Hence, while coal generation constitutes only a marginal share of Italy's energy mix, the phase-out of the above 8 coal power plants will result in over $25,000 \mathrm{Gg} \mathrm{CO}_{2} \mathrm{eq} / \mathrm{year}$, thus nevertheless leading to a positive trade-off in terms of curbing GHG emissions nation-wide as compared to similar setups in other member states. This clearly advocates for a swift implementation of the policy enshrined in Italy's NECP.

\subsection{The Current Italian Policy Context for Coal Phase-Out Between Ambitious Objectives and EU Constraints}

The current overarching framework for action towards the de-carbonization of the Italian energy sector has been first set in the 2017 National Energy Strategy (NES), enacted through an Inter-Ministerial Decree of the Ministry of Economic Development, and the Ministry of the Environment, Land and Sea [18]. One of the main objectives of the 2017 NES consists in the deep de-carbonization of the Italian energy system by 2040. This objective, in turn, is grounded on the full phase-out of coal generation by 31 December 2025. As noted above, this would primarily entail safeguarding for the shutdown of the about $8 \mathrm{GW}$ coal-generation capacity currently in operation (as calculated at the maximum production capacity). To this end, the NES lays down an ambitious roadmap to replace coal-fired generation by increasing natural gas generation (up to $1.5 \mathrm{GW}$ ), while fostering RES generation (primarily wind and solar PV). According to the 2017 NES, RES should generate around 55\% of total Italian energy generation by 2030 , as compared to the current $35 \%$ [18].

The key underpinnings of the 2017 NES have been largely transposed and reiterated in the 2019-2020 Italian National Energy and Climate Plan (NECP). The NECP is mandated under the newly enacted Energy Union Governance Regulation [6]. The NECP aims to develop and outline the key set of instruments and goals to attain de-carbonization of the energy sector as part of the key five dimensions of EU's energy union within the context of EU's 2030 climate and energy targets [17]. Importantly, the commitments and actions included in the NECP are binding upon member states. Thus, they will be monitored by the European Commission on a regular basis and may be subject to specific recommendations issued by the same commission in case of non-fulfilment (article 30 governance 
regulation); where persistent non-fulfilment may eventually lead to the EC commencing infringement procedures against member states for non-compliance [8]. According to the submitted Italian NECP, the full coal phase-out by 2025 will be achieved under the following main conditions:

- A massive increase of RES electricity generation-up to 184 TWh in 2030, with a total of at least 52 GW (solar PV) and 19.3 GW (wind) generation capacity [8];

- The full development of key energy infrastructures, primarily with regard to insulated areas (i.e., large islands such as Sicily and Sardinia); for example, a new electricity interconnection between Sardinia, Sicily, and the continent is being looked into, along with new capacity for gas generation or storage capacity of $400 \mathrm{MW}$ located on the island and the installation of condensers for at least 250 MVAR [8];

- The wide deployment of gas-fuelled power stations to ensure flexibility and security of energy supply against peak demand and wide ranges of electrical loads (especially in summer and winter) and to offset for intermittency of RES generation.

Figure 3 below summarizes the ideal priorities and actions envisaged in the 2017 NES and 2019 NECP. Figures 4 and 5 show the evolution of Italian energy generation in the NES/NECP scenario.

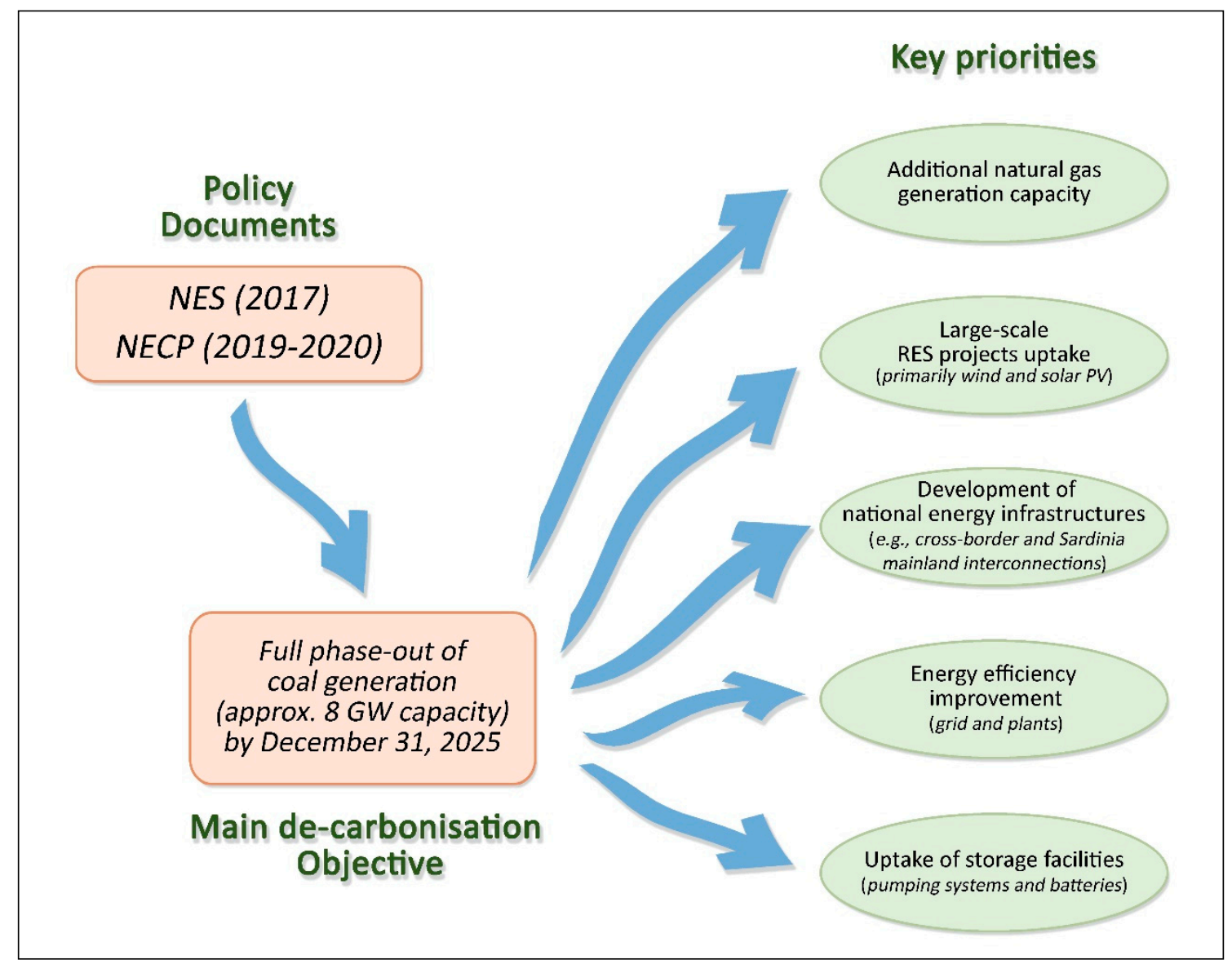

Figure 3. Outline of policy context for coal phase-out in Italy. 


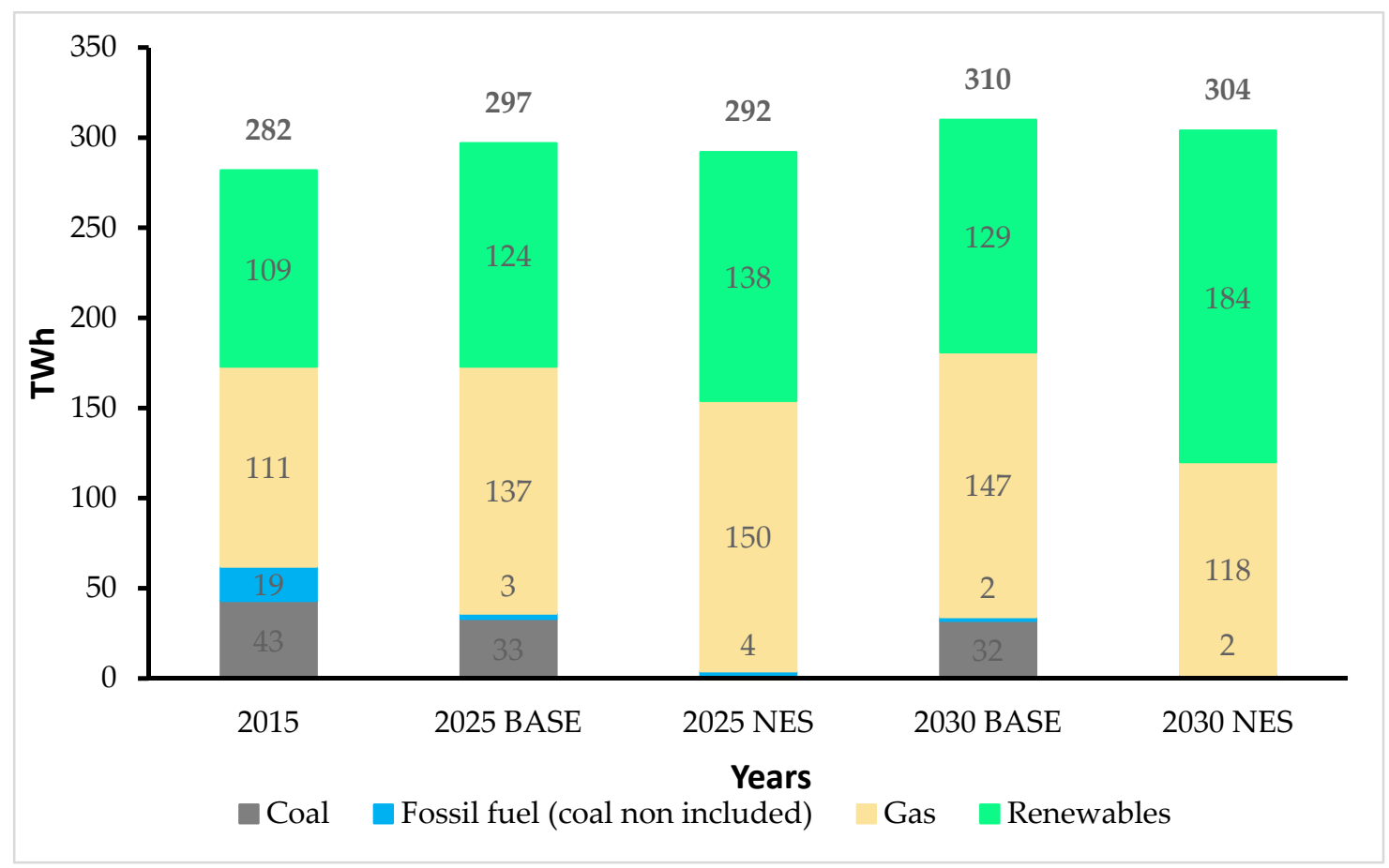

Figure 4. Evolution of Italian energy generation mix in the baseline scenario (based on pre-2014 policies) and the National Energy Strategy (NES)/ National Energy and Climate Plan (NECP) scenario (TWh) [18].

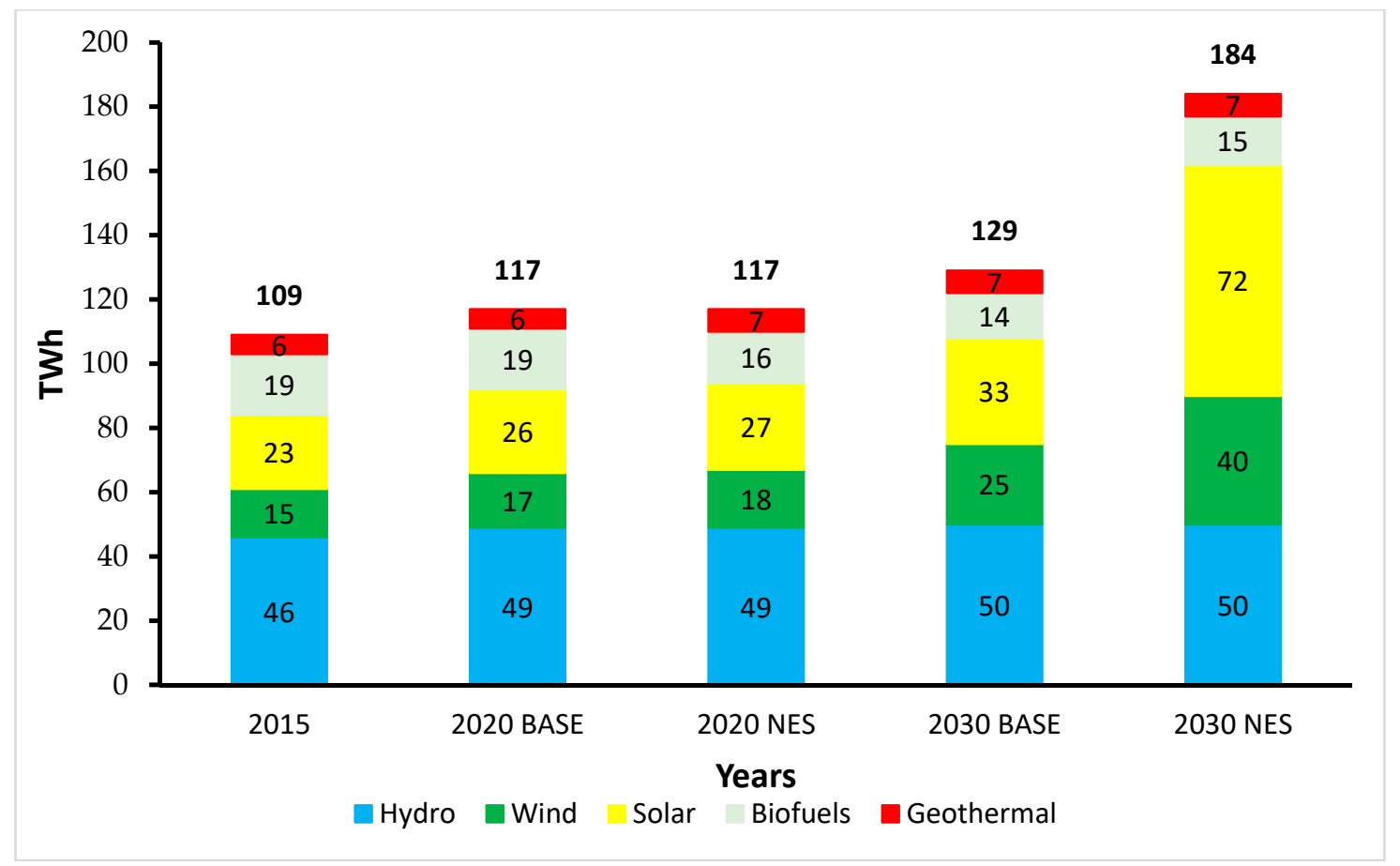

Figure 5. Evolution of Italian RES generation in the baseline scenario (based on pre-2014 policies) and the NES/NECP scenario (TWh) [18].

To further elaborate on the policy framework highlighted above, two key mid- to long-term scenarios can be drawn, which inform the evolution of the key drivers of policy implementation for coal phase-out:

1. The NECP 2025 scenario, developed by the Italian Transmission System Operator (TSO), Terna S.p.A., based on the Italian NECP [19]. This scenario envisages a total phase-out of coal 
power plants as pledged in the same NECP and therefore in a total $9.3 \mathrm{GW}$ capacity reduction (7.9 GW) with a total of $43 \mathrm{GW}$ additional RES (wind and solar PV) capacity through 2030. Accordingly, a 3 TWh demand increase in 2025 (325 TWh) as compared to 2018 (322 TWh) is foreseen, with a total of $54 \mathrm{GW}$ thermal capacity needed as back-up, a total required addition of $3 \mathrm{GW}$ aggregation/storage, and $5.4 \mathrm{GW}$ new generation capacity (mostly acquired through natural gas) [19]. This additional capacity should be mostly $(60 \%)$ allocated in Northern Italy, whereas storage capacity should be mostly allocated in the central and southern areas. Importantly, without such additional capacity, the loss of load expectation (LOLE) value would result in a ten-fold value $(30 \mathrm{~h})$ greater than the standard value adopted at the European and national level (3 h) [19];

2. The Sustainable Transition (ST) scenario, elaborated by the European Network of Transmission System Operators for Electricity (ENTSO-E) [20]. This scenario is based on a rapid and steady reduction of coal generation (and related GHG emissions) as coupled with a $37 \mathrm{GW}$ increase of RES generation (wind and solar PV) through 2030. Accordingly, a 19 TWh demand increase in 2025 (341 TWh) as compared to 2018 (322 TWh) is expected, with a total $56 \mathrm{GW}$ thermal capacity needed as back-up and 5.4 GW new capacity (most entirely through natural gas) [20], although with hardly any increase in storage capacity.

As displayed in Figure 6, the energy demand trend largely diverges between the two above scenarios, where the sustainable transition (ST) scenario proves more energy-intensive over time.

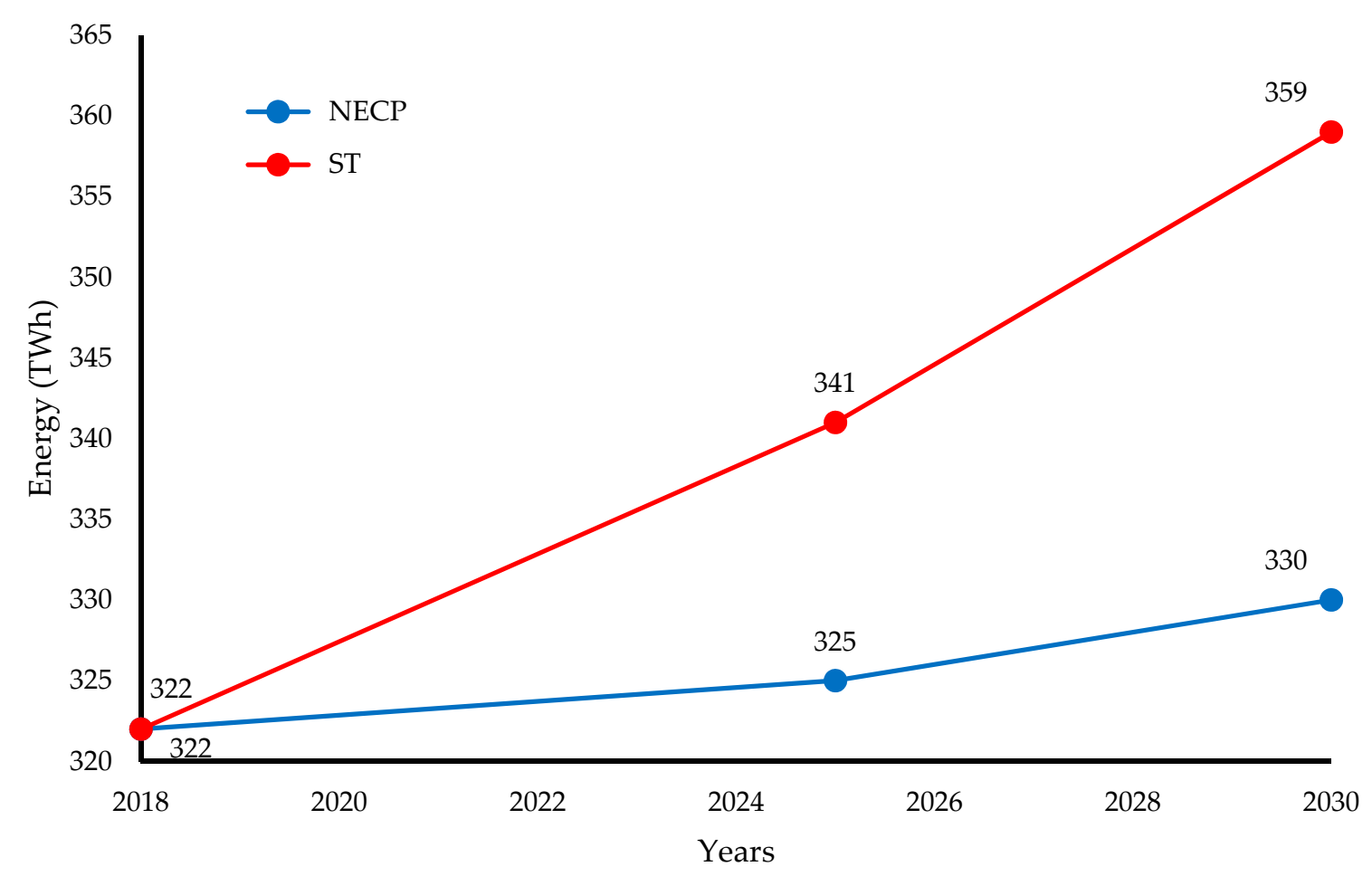

Figure 6. Energy demand versus time for NECP and sustainable transition (ST) scenarios [19].

While resource adequacy assessment methods vary widely among member states, Italy has adopted the s.c. "probabilistic approach" relying on the Monte Carlo method [20]. This approach encompasses demand variations over years as expressed through the loss of load expectation (LOLE). LOLE measures the number of hours per year when, in the long-term, energy supply is statistically expected not to meet demand. The adequate LOLE value for the Italian energy system has been set at $3 \mathrm{~h}$. In the simulation, the LOLE value has been calculated to estimate resource adequacy in the 2025 Low Carbon Sensitivity scenario as compared to the Base-Case scenario, with particular regard to five Italian market zones: North (ITN), Center-North (ITCN), Center-South (ITCS), Sardinia (ITSA), 
and Sicily (ITSI). As displayed in Figure 7, an utmost concern relates to the potential high LOLE value in the Sardinia zone. This is mostly due to the closure of coal-fired generation as coupled with the lack of reciprocal interconnection with the national energy network in the mainland [20].

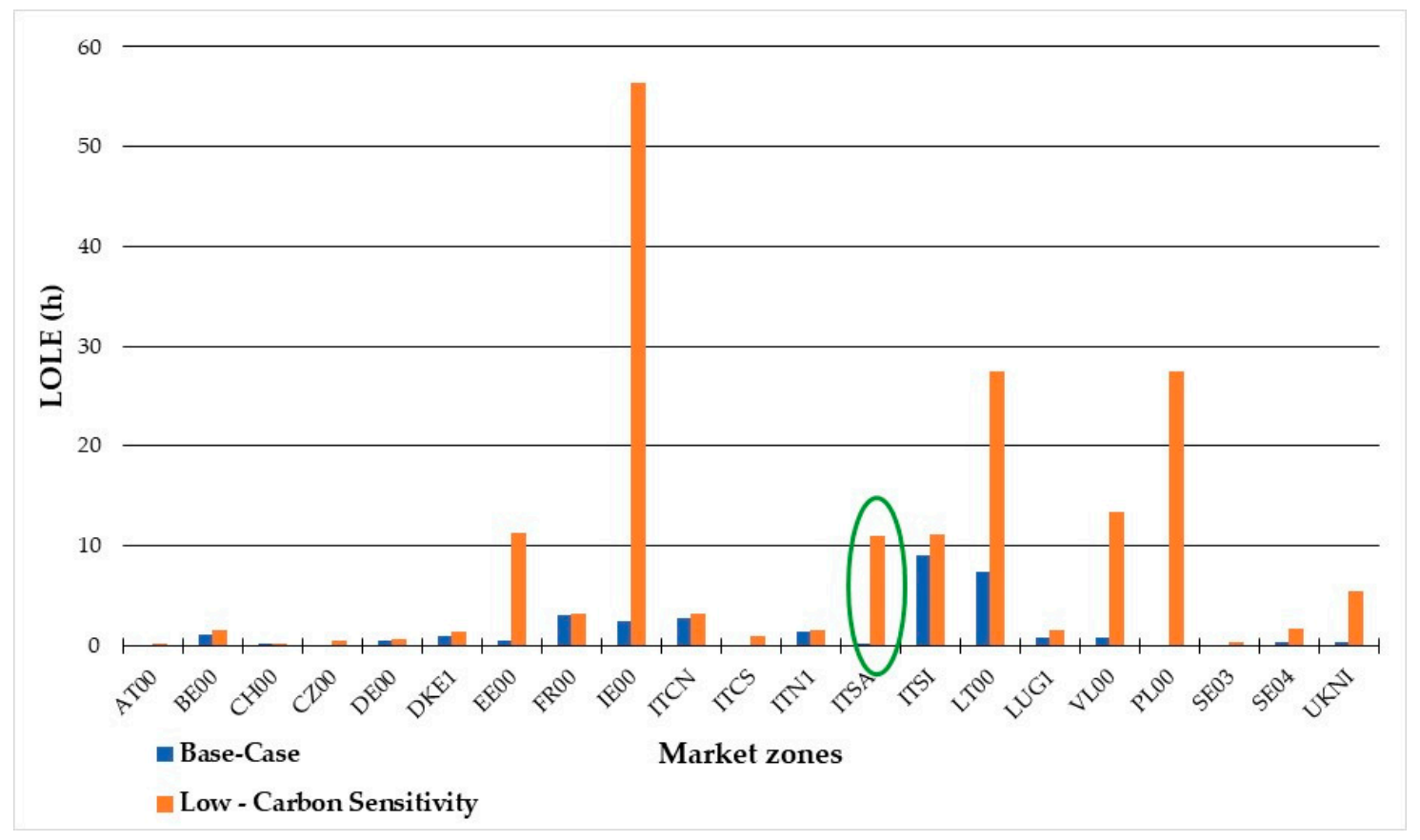

Figure 7. Loss of load expectation (LOLE) values under base-case and low-carbon 2025 scenarios per market zone. Minimum LOLE value: $0.5 \mathrm{~h}$. The green ellipse singles out the market zone: Sardinia [20].

Furthermore, a crucial enabling factor to achieve both the above scenarios rests on adequately providing for stable and reliable long-term price signals. This will steer investments in additional generation capacity both by retrofitting/repowering of existing thermal plants (including the eight existing coal power plants), and by prompting the development of large-scale RES installation projects (also in order to increase storage capacity). Hence, the focus of the following sub-sections is on the main tools adopted to ensure such outcomes, namely: (a) the capacity mechanism (CM) and (b) the support to RES generation through RES auctions and long-term power purchase agreements (PPAs), respectively.

\section{Legal Pathways to Coal Phase-Out in Italy}

\subsection{Capacity Mechanism}

The Italian CM has been put into operation through the Ministerial Decree 28 June 2019 after previous approval by the European Commission in 2018. Its primary aim is guarantee adequate back-up capacity for base-load and peaks (especially in deep winter and summer), while channeling investments towards new generation capacity [8]. According to Terna S.p.A.'s calculations, an additional $5.4 \mathrm{GW}$ natural gas generation will be needed to this end in light of coal generation phase-out in 2025 [21].

Capacity mechanisms are defined and regulated under article 2(22) of the Electricity Regulation (No. 2019/943). Capacity mechanisms can be designed as price-based mechanisms, or volume-based mechanisms. In the price-based mechanisms, the price for allocated capacity is set by policymakers in advance to ideally square the level of investments needed and the amount of capacity required. Thus, it is left up to generators participating in the mechanism to decide how much volume of capacity they are willing to invest in for the given price. In the volume-based mechanisms, the total capacity required is determined in advance by central authorities or by a designated entity (e.g., the TSO). The price for the capacity allocated is then established through different market-based processes. 
The current Italian legislator opted for a volume-based capacity mechanism. The pre-set capacity volume is allocated through 7 zonal forward auctions (four years ahead), managed centrally by the Italian TSO (Terna S.p.A.). In order to ensure technology neutrality, capacity auctions are open to both existing and future generation capacity, demand-side, aggregators, and foreign capacity providers-including generators, demand-side, and storage facilities. Alongside the four-year-ahead capacity auctions, annual ancillary auctions mat be carried out, in order to re-calibrate the capacity allocated in light of adequacy resources concerns. As a result of the capacity auctions, the bidding capacity providers stipulate an option procurement contract with the TSO, the Reliability Option (RO). Under the RO, generators are granted the option to generate electricity at a predetermined strike price plus an annual fixed premium $(€ / \mathrm{KW})$. In return, generators bear an obligation to dispatch electricity above the strike price in case of peak demand overshooting the originally allocated capacity; with an additional obligation to surrender the positive net-difference between the strike price and the option price. The existing capacity enters $\mathrm{RO}$ for a duration of three years, while new capacity is granted a fifteen-year RO.

In 2019, the first two CM auctions were conducted by Terna S.p.A. to grant a remarkable share of electricity generation capacity, mostly for domestic needs. The first auction (6 November 2019) granted capacity for 2022 as the reference year, where the second auction (28 November 2019) covered projects to be implemented and generating capacity in 2023. In total, some $83 \mathrm{GW}$ capacity has been assigned through the auctions, as displayed in Tables 5 and 6 below.

Table 5. Granted capacity under the 2022 capacity auction [22].

\begin{tabular}{|c|c|c|c|c|c|c|}
\hline \multirow[b]{2}{*}{$\begin{array}{c}\text { Area } \\
\text { (Geographic) }\end{array}$} & \multicolumn{2}{|c|}{ Existing } & \multicolumn{2}{|c|}{ New Capacity } & \multicolumn{2}{|c|}{ Non-Domestic Capacity } \\
\hline & $\begin{array}{l}\text { Capacity } \\
(\mathrm{MW} / \mathrm{y})\end{array}$ & $\begin{array}{l}\text { Premium } \\
(€ / M W / y)\end{array}$ & $\begin{array}{l}\text { Capacity } \\
\text { (MW/y) }\end{array}$ & $\begin{array}{l}\text { Premium } \\
(€ / M W / y)\end{array}$ & $\begin{array}{l}\text { Capacity } \\
(\mathrm{MW} / \mathrm{y})\end{array}$ & $\begin{array}{l}\text { Premium } \\
(€ / M W / y)\end{array}$ \\
\hline North & 21,465 & 33,000 & 1276 & 75,000 & 4241 & 4400 \\
\hline Center-North & 1272 & 33,000 & 49 & 75,000 & - & - \\
\hline Center-South & 4233 & 33,000 & 305 & 75,000 & 104 & 3449 \\
\hline South & 2581 & 33,000 & 84 & 75,000 & 49 & 4000 \\
\hline Calabria & 3185 & 33,000 & 0 & 75,000 & - & - \\
\hline Sicily & 1878 & 33,000 & 53 & 75,000 & - & - \\
\hline Sardinia & 144 & 33,000 & 0 & 75,000 & - & - \\
\hline Total & 34,758 & - & 1767 & - & 4394 & - \\
\hline
\end{tabular}

Table 6. Granted capacity under the 2023 capacity auction [23].

\begin{tabular}{|c|c|c|c|c|c|c|}
\hline \multirow[b]{2}{*}{$\begin{array}{c}\text { Area } \\
\text { (geographic) }\end{array}$} & \multicolumn{2}{|c|}{ Existing } & \multicolumn{2}{|c|}{ New Capacity } & \multicolumn{2}{|c|}{ Non-Domestic Capacity } \\
\hline & $\begin{array}{c}\text { Capacity } \\
\text { (MW/y) }\end{array}$ & $\begin{array}{l}\text { Premium } \\
(€ / M W / y)\end{array}$ & $\begin{array}{l}\text { Capacity } \\
\text { (MW/y) }\end{array}$ & $\begin{array}{l}\text { Premium } \\
(€ / M W / y)\end{array}$ & $\begin{array}{l}\text { Capacity } \\
\text { (MW/y) }\end{array}$ & $\begin{array}{l}\text { Premium } \\
(€ / M W / y)\end{array}$ \\
\hline North & 21,284 & 33,000 & 2631 & 75,000 & 4241 & 4400 \\
\hline Center-North & 1308 & 33,000 & 65 & 75,000 & - & - \\
\hline Center-South & 4651 & 33,000 & 804 & 75,000 & 104 & 4949 \\
\hline South & 2927 & 33,000 & 162 & 75,000 & 49 & 3999 \\
\hline Calabria & 2891 & 33,000 & 0 & 75,000 & - & - \\
\hline Sicily & 1797 & 33,000 & 342 & 75,000 & - & - \\
\hline Sardinia & 155 & 33,000 & 0 & 75,000 & - & - \\
\hline Total & 35,013 & - & 4004 & - & 4394 & - \\
\hline
\end{tabular}

All capacity ( $40.919 \mathrm{GW}$ ) has been allocated in the 2022 auction (see Table 5). Renewable energy sources have been assigned in total $1 \mathrm{GW}$ capacity. Out of total $1.767 \mathrm{GW}$ new capacity, $1.401 \mathrm{GW}$ encompasses installations that have not yet obtained the mandatory permit for operation, while the remaining $0.366 \mathrm{GW}$ has obtained the permit to operate.

All capacity ( $43.411 \mathrm{GW}$ ) has also been allocated in the 2023 auction (see Table 6). Renewable energy capacity has been granted in total 1.3 GW capacity. Out of total 4.004 GW new capacity, 3.476 GW 
thereof comprises installation that has not yet obtained the relevant permit to operate, while the remaining $0.528 \mathrm{GW}$ has obtained the needed permit to operate.

Thus, importantly, a prominent share of the projects that have been earmarked capacity under the CM 2019 auctions are currently under review for obtaining the relevant permits under national legislation on environmental impact assessment (EIA) and industrial emissions. In order to ensure fast processing of the relevant permitting procedure, the RO contracts signed between the TSO and the capacity generators under the $\mathrm{CM}$ mandate the same permits to be obtained in due course (i.e., 30 June 2020 for 2022; 31 December 2020 for 2023) for the payment of annual fixed premiums to apply.

In addition to this concern, three main underlying pitfalls characterize the design and implementation of Italy's CM. First, the current allocation of generation capacity clearly shows a robust upward trend in natural gas generation. In 2018, natural gas generation in Italy amounted for $44.8 \%$ of Italian energy generation mix with a total of 130 TWh electricity produced (see Table 1 ). This share is set to further increase over the next ten years as a result of additional generation capacity to be installed and granted remuneration through the $\mathrm{CM}$. According to current predictions, the phase-out of about $8 \mathrm{GW}$ coal-fired capacity will entail an increase in natural gas consumption between 24 and 33 TWh in 8 years between 2017 and 2025 [21]. Such a trend diverges considerably from that embraced at both the global and EU level, which sets an overall $24 \%$ share of natural gas generation (excluding capacity equipped with Carbon Capture and Storage, CCS or Carbon Capture and Utilisation, CCU), with a total of approximately $450 \mathrm{TWh}$ EU-wide aggregated production under current policies in 2040 [24]. The European Commission has thus remarked how the centrality of gas in Italy's future energy mix constitutes a major contradiction with the stated de-carbonization objectives in the NECP [25]. In fact, as displayed in Table 7, it is fair to assume that a large upscale of natural gas generation without the use of ancillary technologies to reduce the GHG impact thereof (such as CCS or $\mathrm{CCU})$ could ultimately undermine in the long term the net climate and environmental benefits gained from coal-fired generation phase-out in the short term [26].

Table 7. Greenhouse gases (GHG) emissions from thermoelectric generation in Italy ( $\left.\mathrm{Gg} \mathrm{CO}_{2} \mathrm{eq}\right)$ [27].

\begin{tabular}{cccc}
\hline Fuels & \multicolumn{3}{c}{ Years } \\
& $\mathbf{1 9 9 0}$ & $\mathbf{2 0 1 3}$ & $\mathbf{2 0 1 7}$ \\
\hline Solids & 28,100 & 39,900 & 28,600 \\
Natural Gas & 21,000 & 48,500 & 60,700 \\
Derived Gases & 6700 & 5900 & 4500 \\
Oil Products & 70,200 & 12,400 & 8800 \\
Other Fuels & 100 & 3400 & 3500 \\
Total & 126,100 & 110,100 & 106,100 \\
\hline
\end{tabular}

Second, the $\mathrm{CM}$ as a regulatory tool to manage energy production overtly relies on uncertain forecasts for future conditions and overall electricity demand - with specific regard to peak loads [28]. This may hamper the proper functioning of the electricity market on various grounds. First, deviations between baseline forecasts and actual electricity demand may result in distortions of the market as to electricity price formation. Second, poor price calibration might result in increased electricity bills on end users without improved supply security [29].

Third, nation-based generation adequacy assessment might fall short in ensuring an integrated and coordinated energy market, thus creating cross-border distortions [30]. According to the newly enacted electricity regulation (articles 22 and 24), both newly established and existing capacity mechanisms shall be subject to constant review to ascertain adequacy concerns to ensure they ultimately downplay structural electricity market reforms [31]. In this regard, the Italian CM provides for an annual review to be conducted by Terna S.p.A.. If the resource adequacy assessment displays overcapacity through the $\mathrm{CM}$, the competent authority shall undertake a resource adequacy assessment, which will in any event be coupled with a European adequacy assessment to be carried out by ENTSO-E. According to article 21(6) of the electricity regulation, if the national and/or European resource adequacy assessment 
has not identified a resource adequacy concern, the EU member states shall not grant new right or stipulate contracts under the capacity mechanism. If the European/national adequacy assessment shows resource adequacy concerns, member states shall then publish an implementation plan to adopt a set of measures to adequately remove the identified regulatory distortions and/or market failures (including capacity mechanisms). Hence, in light of the electricity regulation, capacity mechanisms shall constitute the last resort to eliminate resource adequacy concerns (article 21(1) energy regulation).

\subsection{RES Auctions and Power Purchase Agreements (PPAs) for RES Generation Capacity}

To ensure a swift increase in RES generation after a stagnation due to the termination of support schemes in 2013, Italy relied on a twofold set of instruments as outlined in the NECP to provide a more stable long-term price signal. These instruments have been set up in the (long awaited) Ministerial Decree 4 July 2019 (RES decree). All support schemes for RES, however, are applicable only to a limited sub-set of RES technologies (on-shore wind, solar PV, hydroelectric, and sewage gas installations), albeit are deemed to operate in a technology-neutral fashion (article 3 RES decree). First, an ambitious auctioning regime for RES capacity has been set up with regard to installations with >1 MW generation capacity (or aggregators of installations ranging from 20 to $500 \mathrm{KW}$ ); the total capacity granted through RES auctions equals $6230 \mathrm{MW}$ [32]. Second, a set of nation-wide registries aimed to provide remuneration for small-scale installations with $<1 \mathrm{MW}$ generation capacity (including aggregators from a minimum of 1 , or $20 \mathrm{~kW}$ for solar PV); the total capacity granted under the registries regime equals $1770 \mathrm{MW}$ [32]. Given the timeframes for entering into operation of the assignee installations mandated in the RES decree, a total of $8 \mathrm{GW}$ capacity is expected to be operational by 2026 as a result of the RES auctions and registries, with $6.5 \mathrm{GW}$ thereof generated by wind and solar PV [32].

To adequately compensate for the gradual backrolling of incentives for RES generation towards their full market parity and competition on the market with other energy sources as envisaged in the EU electricity directive (no. 2019/944) and electricity regulation, long-term power purchase agreements (PPAs) have been put in place since the adoption of the NES in 2017. PPAs are stipulated between RES generators (sellers) and power purchasers (off-takers). PPAs are aimed to enhance RES projects' mid- to long-term financial stability, and therefore contribute to ensure their bankability of vis-à-vis lenders (e.g., commercial banks or private equity funds). Moreover, PPAs address demand and pricing uncertainties resulting from RES generation by incorporating a (mid- to) long-term purchase obligation on the offtaker and setting a tariff price that reflects the actual cost of power generation. PPAs are understood as a viable legal tool to foster large-scale RES projects as they shield energy generators, energy purchasers, and lenders from the risks associated with shocks in energy market prices or abrupt regulatory changes in RES support schemes [33]. Against this backdrop, ideally PPAs should serve primarily the development and repowering of RES projects with high upfront investments and low operational and maintenance costs, such as large-scale (onshore and offshore) wind or solar PV installations. The most common PPAs negotiated on the market are: Utility PPAs, where the offtaker is a energy trader or energy utility; corporate PPAs, where the offtaker is an end-user (tipically an industry or business); and government PPAs, where the offtaker is a governmental or public body [34].

While PPAs constitute a novel tool for the Italian energy market, they are rather widespread in several other legal systems worldwide. In 2019, PPAs generated a total volume of approximately 30 GW globally, mostly in the US (see Figure 8). 


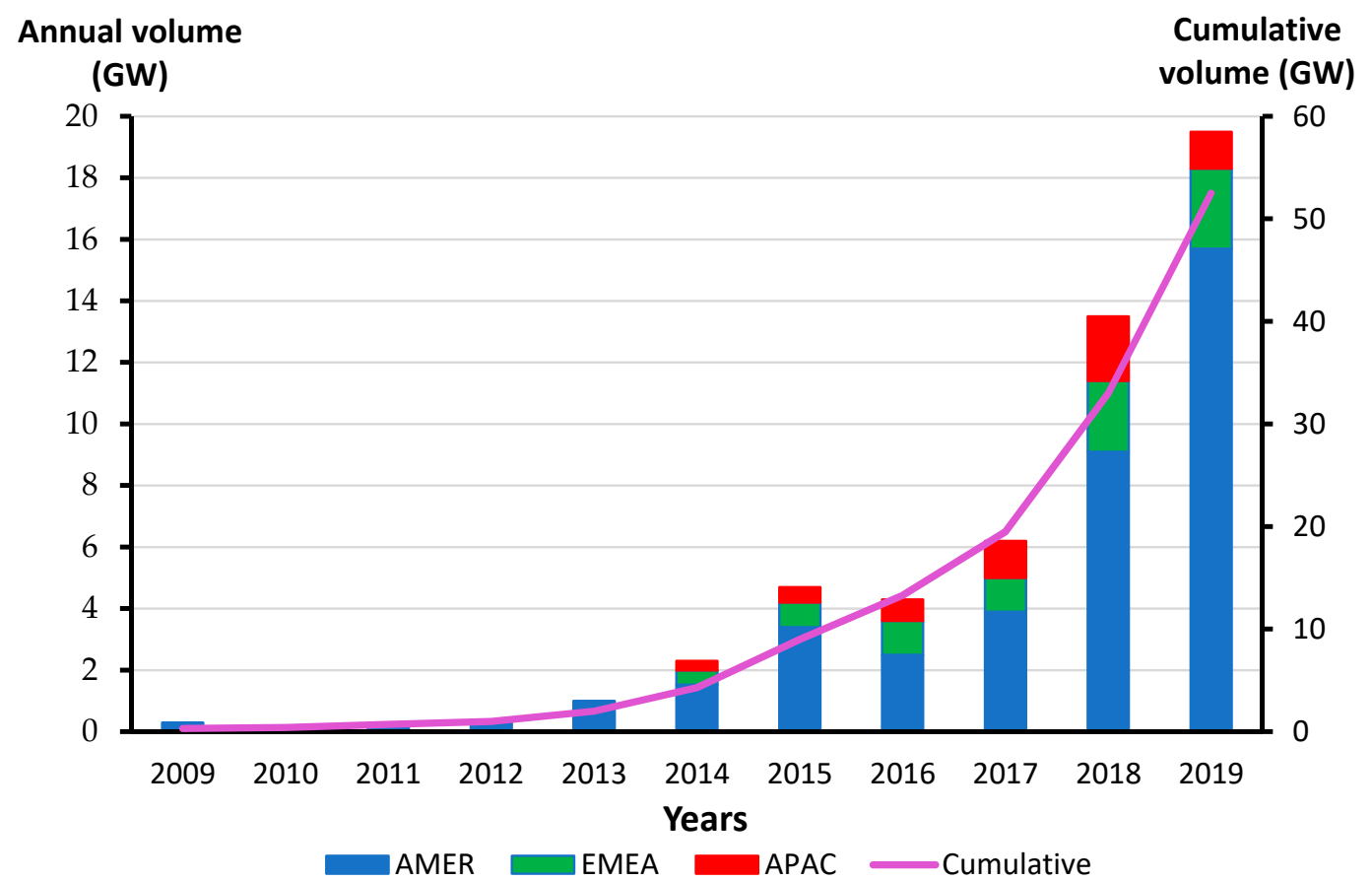

Figure 8. Total volume of corporate power purchase agreements (PPAs) (where AMER = Americas Region, EMEA = Europe, Middle East, and Africa, APAC = Asia Pacific) [35].

The vast majority of PPAs negotiated on the Italian market thus far provide for short-term (typically one year) and indexed prices, linked to the price determined on the energy organized market (IPEX). Yet drawing from the experience of other European markets and as a consequence of the recent swift changes to the Italian support schemes for RES generation, medium- to long-term PPAs (up to 10 years) are increasingly being negotiated. Differently from short term/indexed PPAs, such contracts allow sellers/generators to share (or shift) to the off-taker the risks stemming from electricity market price (price risk) and from unpredictability due to intermittency of RES like sun or wind (volume risk).

The Italian PPAs market has been undoubtedly halted, however, due to the delays in the enactment of the RES decree. Nevertheless, in 2019, approximately 500 MW capacity has been negotiated under PPAs in Italy, all in the form of utility PPAs (see Table 8). This clearly shows the need to further develop this tool in order to embed large, energy consuming companies (e.g., hi-tech and heavy-industry companies) as RES off-takers.

Table 8. RES PPAs' negotiated contracts in the Italian market (2018-2020) [36].

\begin{tabular}{|c|c|c|c|c|c|}
\hline Off-Taker & Developer/Generator & $\begin{array}{c}\text { Duration } \\
\text { (Years) }\end{array}$ & $\begin{array}{c}\text { RES } \\
\text { Technology }\end{array}$ & Power/Energy & Date \\
\hline Wienerberger & Engie & 5 & Solar PV & $\mathrm{n} / \mathrm{a}$ & Feb. 2018 \\
\hline EGO & Octopus & 5 & Solar PV & $40 \mathrm{MW}$ & Mar. 2018 \\
\hline EGO & Octopus & 5 & Solar PV & $63 \mathrm{MW}$ & Dec. 2018 \\
\hline Trailstone & $\begin{array}{l}\text { Canadian Solar, } \\
\text { Manny Energy }\end{array}$ & 10 & Solar PV & $18 \mathrm{MW}$ & Dec. 2019 \\
\hline Shell & Octopus & 5 & Solar PV & 71 & Dec. 2020 \\
\hline Axpo & $\begin{array}{l}\text { European Energy } \\
\text { (Framework PPA) }\end{array}$ & 12 & Solar PV & $\begin{array}{c}150(+150) \\
\text { MW }\end{array}$ & Jan. 2019 \\
\hline Audax Renovables & Base FV & 10 & Solar PV & $20 \mathrm{MW}$ & Jan. 2020 \\
\hline DXT Commodities & Fera & 7 & $\begin{array}{l}\text { Wind } \\
\text { (Onshore) }\end{array}$ & $200 \mathrm{GWh}$ & Apr. 2019 \\
\hline
\end{tabular}

To promote the conclusion of PPAs, a PPA online platform for negotiation will be put into operation before the end of 2020 under the management of the Gestore dei Mercati Energetici (GME) pursuant to the 
RES decree. This should provide for a larger floor for negotiations while reducing negotiation risks and insolvency risks by having the GME as intermediary, proof-checking financial stability of negotiating parties, and adopting a standard contract. Importantly, all PPAs stipulated over the counter should be registered in the PPA platform, thus ensuring GME's intermediary role between the parties thereof. At the same time, the online platform should contribute to better align the strike price with the actual energy prices. This should in turn prevent under/over remuneration of investments, thus empowering buyers/off-taker to leverage PPAs as an hedging tool to floor the energy price. One of the key pitfalls stemming from mis-matches between PPAs' price and market price, moreover, relates to the risk of such a gap being passed on to end users.

Whilst the long-awaited auctions for RES generation, combined with the enter into force of the CM for both natural gas and (to a lesser extent) RES generation, arguably enhance medium- and long-term price signal stability, two main lingering factors hinder the effective adoption of PPAs as a means to foster RES generation. First, actual over-remuneration of generation capacity under the CM might render new/repowered large-scale RES installations less appetible, and therefore negatively impact on PPAs. Second, the delays and uncertainties in the permitting procedures for RES installations (as well as for key grid infrastructures) thwart full integration of RES in the energy market. Without a viable and effective institutional and regulatory framework to ensure legal and timeframe certainties for permitting procedures under relevant regulation-primarily, EIA and related assessments, such as the landscape impact assessment, backed with additional investments in manpower and expertise for local public administrations, eventual contracting parties may still take a cautious, if not reluctant, approach towards PPAs for new RES installations [34,36].

\subsection{Siting of Energy Infrastructures and RES Installations}

The vast majority of the relevant installations participating to the capacity market and subject to PPAs are subject to mandatory permitting procedures under Italian spatial planning and environmental law. In particular, all natural gas plants and distribution infrastructures fall into the scope of the Industrial Emission Directive (no. 2010/75/UE, IED). Conversely, both newly built and renovated/ revamped large-scale RES installations must be subject to EIA pursuant to directive no. 2011/92/EU.

In Italy, the management of installations falling within the scope of the IED is regulated through the release of the Autorizzazione Integrata Ambientale (AIA). The conditions and standards contained in the AIA are subject to review on a regular basis to ensure adequate calibration with regard to the plant's actual performances. The Italian Ministry of Environment, Land and Sea is the competent authority for such review with regard to thermal power plants with $>300 \mathrm{MW}$ capacity. In November 2018, the same ministry started the comprehensive review of all existing AIA in light of the best available techniques (BATs) as enlisted in the European Commission's BAT Reference Document in the Commission Implementing Decision no. 2017/1442/EU (BRefs). Importantly, with specific regard to coal-fired power plants, AIA reviews will both set key operation conditions in line with BRefs by August 2021, and finally set the operational limit of coal generation as to 31 December 2025 in line with the NECP (see Table 9 below). Ahead of the announced shutdown of coal power plants in 2025, applications for repowering projects have been submitted to the Italian Ministry of the Environment, Land and Sea with regard to 5 out of 8 existing coal power plants. All such repowering projects consist in natural gas installations (through combined cycle gas turbines, CCGTs) subject to EIA. No application has been submitted for the Lamarmora (Brescia) plant since the existing generation unit (multi-fuel type) is already set to run by natural gas. Importantly, operators of the two remaining coal power plants located in Sardinia (Sulcis, Portoscuso and Fiume Santo) have not yet applied for repowering due to the lack of interconnection between the same Sardinia island and the national gas distribution network on the mainland. 
Table 9. State of the art of Autorizzazione Integrata Ambientale (AIA) permitting procedures for existing coal-fired power plants [15].

\begin{tabular}{ccc}
\hline $\begin{array}{c}\text { Coal-Fired } \\
\text { Combustion Plant }\end{array}$ & $\begin{array}{c}\text { Existing IED (AIA) Permit for } \\
\text { Coal Generation } \\
\text { (To Expire on } \\
\text { 31 December 2025) }\end{array}$ & $\begin{array}{c}\text { EIA Permit } \\
\text { (Natural Gas Repowering } \\
\text { Projects) }\end{array}$ \\
\hline $\begin{array}{c}\text { Ministerial Decree no. 284/2019 } \\
\text { (30 September 2019) } \\
\text { Civitavecchia (RM) }\end{array}$ & $\begin{array}{c}\text { Pinisterial Decree no. 84/2020 } \\
(21 \text { April 2020) }\end{array}$ \\
Brindisi & $\begin{array}{c}\text { Ministerial Decree no. 50/2020 } \\
(27 \text { February 2020) }\end{array}$ & Pending \\
Monfalcone (GO) & In progress & Pending \\
Fusina & In progress & Pending \\
Porto Marghera (Venice) & n/a \\
Lamarmora (Brescia) & Ministerial Decree no. 351/2019 \\
La Spezia & Ministerial Decree no. 37/2020 & Pending \\
Sulcis, Portoscuso (SU) & $(13$ February 2020) & n/a \\
(Sardinia) & Ministerial Decree no. 85/2020 & n/a \\
Fiume Santo (SS) & (22 April 2020) & \\
\hline
\end{tabular}

As displayed in Figure 9 below, most of the projects participating in the $\mathrm{CM}$ and already granted capacity thereunder are still undergoing the relevant permitting procedures (EIA), managed at the state level, before entering into operation.

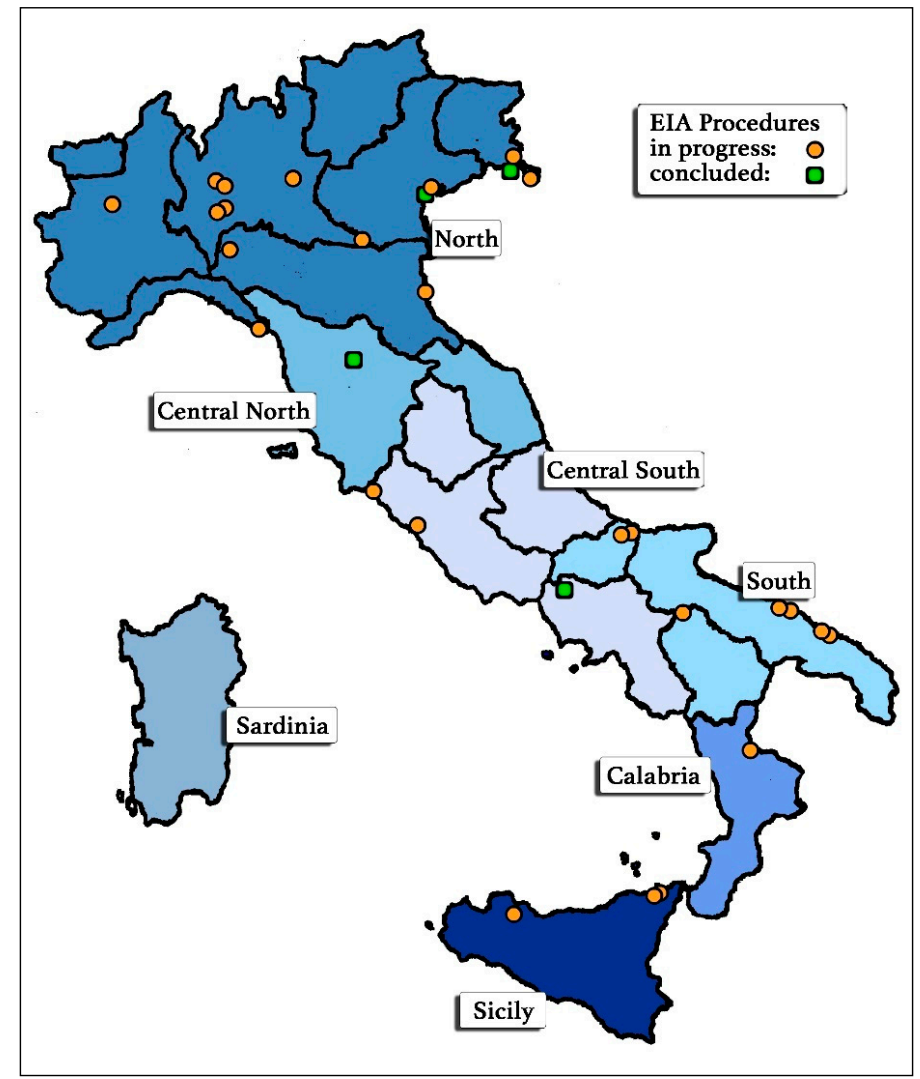

Figure 9. State of the art of permitting procedure for capacity market installations [37].

Furthermore, large-scale RES installations fall within the scope of the impact assessment procedures pursuant to legislative decrees no. 2003/387 and no. 28/2011. Accordingly, regional and local 
administrations retain competence as to the carrying out of the permitting procedure, while the state level retains such competence with regard to all off-shore installations, on-shore wind, and hydroelectric plants with $>30 \mathrm{MW}$ generation capacity. Large-scale RES installations (wind installation with $>60 \mathrm{~kW}$, solar PV $>20 \mathrm{~kW}$, biomass $>200 \mathrm{~kW}$, and biogas $>250 \mathrm{Kw}$ ) are subject to Autorizzazione Unica (AU) pursuant to article 12, legislative decree no. 387/2003. AU encompasses all relevant permits, including EIA (where required) and those related to landscape and biodiversity impact (under the EU Natura 2000 framework), as well as those required under relevant urban planning regulations and are entirely managed at the regional level. Small-scale installations are instead subject to simplified procedures. Moreover, national AU guidelines for RES installations have been issued in 2010 with regard to the criteria for siting of RES installations, thus arguably overcoming the long-standing issue of allocation of competences for the siting of RES installations between the state and regional level [38].

Notwithstanding such relevant steps towards harmonization and streamlining of permitting process for RES generation, however, several discrepancies remain as to the degree of stringency of permitting regulation across different Regions. For example, four regions (Vallée d'Aoste, Province of Bolzano, Umbria, and Sardinia) mandate the EIA procedure for all onshore wind power projects, while other regions mandate EIA only for $>1 \mathrm{MW}$ installations [39]. Likewise, four regions mandate AU for $>100 \mathrm{~kW}$ (Vallée d'Aoste) and $>200 \mathrm{~kW}$ (Province of Trento, Liguria, and Marche), as compared to the national overall $>1 \mathrm{MW}$ threshold [39]. Permitting procedures for RES installations in most cases exceed the maximum duration set by national legislation for AU, mostly due to regional and local's administrations lack of capability to deal with the load of the submitted applications. At present, out of the 346 permitting applications for wind projects submitted in 11 Italian regions (Apulia, Basilicata, Campania, Sicily, Sardinia, Calabria, Liguria, Marche, Molise, Piedmont, Emilia-Romagna), 170 have been granted the permit (equalling 2.8 generation capacity), while the other permits applications are still pending (equalling $6.9 \mathrm{GW}$ generation capacity). The average duration of the permitting procedures under AU and EIA ranges from 1 year for $<6 \mathrm{MW}$ installations in Sicily to over 8 years for 6 to $30 \mathrm{MW}$ installations in Apulia [34]. For solar PV projects, out of 91 permit applications submitted in six Italian regions (Lazio, Sicily, Apulia, Basilicata, Calabria, Campania), 18 have been granted the relevant permit (equalling $940 \mathrm{MW}$ generation capacity), with the remaining projects amounting to a total of $1.7 \mathrm{GW}$ generation capacity [34].

On top of the above local-specific concerns, the Italian NECP envisages substantial amendments to the 2010 guidelines for siting of large-scale RES installations, to be agreed upon between the state government and all regional administrations. Without a prompt adoption of a clear-cut mechanism of allocation and transfer of responsibilities between different levels of decision-making (state-regional-local), this could increase legislative and regulatory uncertainty and ultimately frustrate the development of new RES projects. Importantly, the lingering uncertainties as to the timing and administrative burden of permitting procedures for RES installations are substantially acting against the conclusion of RES PPAs as a key tool to enhance RES projects financial viability in a market-parity scenario.

Amidst the recent COVID-19 outbreak and in order to jump-start strategic infrastructures under the NECP, the law decree no. 76/2020 has been enacted on 15 July 2020. Among several novelties, this decree provides for a substantial review of the general administrative requirements for the relevant permitting procedures under Italian law (Leg. Decree no. 152/2006). In this regard, specific fast-track procedures and rules for the issuance of the relevant permits (EIA, AIA) for those projects included in the NECP or those functional to its full implementation are provided for. In addition, an iterative process to identify further strategic NECP projects is put in place. According to the same Italian NECP, such strategic projects will primarily comprise those related to the national electricity transmission and gas distribution networks, as well as other pivotal interconnectors (importantly including that between the Sardinian island and the mainland). The new regulatory setup adopted by decree no. 76/2020 applies to both newly undertaken and pending EIA (including EIA screening) and AU procedures 
for wind and solar PV projects. Last, the decree has introduced an ad hoc permitting procedure for electrochemical energy storage (batteries).

\section{Discussion and Conclusions}

This article has provided a comprehensive account of the phasing out of coal-fired generation in Italy. Our analysis has shown that Italy is well positioned to deliver on its commitment to achieve full phase-out all coal-fired generation in 2025 as pledged in its 2017 NES and 2019 NECP. In fact, coal-fired generation in Italy constitutes only a marginal share of electricity and thermal generation, moreover facing a steady declining trend of $-38 \%$ in 5 years (2013-2018). Such a decline is largely due to an upsurge in natural gas and RES generation as a result of a notable shift towards de-carbonization in Italy's energy policy since the early 2000s. Notably, this appears to contradict empirical findings showing an inherent trend of resistance to swift coal-phase out in market economies with institutionalized employment protection, governmental ownership and broad consensual processes (such as Italy), as contrasted to liberal market economies (e.g., the UK) [11].

To appraise the mutual correlation between such declining path of coal and each specific policy and regulation is out of the scope of this contribution. Nonetheless, our findings unfold a rather consistent policy path to the closure of coal-fired generation in Italy, as compared to a more "flip-flop" approach adopted in other European countries (e.g., The Netherlands) [40].

This paper has analysed the main regulatory tools adopted in Italy to ensure base-load capacity, duly compensate for the increasing share of intermittent RES in the energy mix, and foster RES generation in light of the coal phase-out. The experience gained with the implementation of such policy-mix as outlined in Section 4 aims thus to provide lessons and insights for similar research both with regard to the Italian context and elsewhere.

Energy security concerns have been addressed in Italy by enhancing flexibility and resource adequacy through the establishment of a capacity mechanism. The design of the Italian CM as a market-based regulatory tool seems adequate as such to provide the correct wholesale market signal as it is market-wide, technology neutral, and allows for (albeit limited) cross-border participation [41]. Notwithstanding the ramping up of RES in Italy, however, it is hardly possible to foresee major flexibility problems in the Italian energy system, which is already largely dominated by natural gas, moreover with a significant back-up and hydropower capacity and a developing demand response and storage capacity. Differently, the Italian CM would rather serve to the need to avoid decommissioning of a number of existing natural gas installations (more specifically, combined Cycle gas turbines, CCGTs), as well as to ensure investments in the revamping or conversion of current coal power generation units into natural gas power units (mostly, CCGTs) as of 2025.

Literature has shown that once capacity mechanisms are implemented, they become the main driver of investments (as opposed to energy prices) in new generation capacity [42]. If capacity mechanisms are excessively biased towards a set of resources, however, they might well result in introducing distorted conditions in the short-term energy markets and lock-in emerging technologies [43]. This risk is particularly high in the case of the Italian CM, given that the Italian system is already characterized by significant overcapacity [44]. Hence our findings denote a clear evolutionary trend of Italy's energy mix towards an over-predominance of natural gas generation, whose impacts in terms of GHG emissions may hinder the net-gains resulting from a coal generation phase-out-moreover not proving aligned with the overall trajectories and roadmap set by mid-to long term EU policies. This has clearly been stressed by the European Commission in its assessment of the Italian NECP as a point that requires further inquiry [25]. This could put the very existence of the CM into question, also in light of the strict adequacy review mechanism introduced by the 2019 Energy Regulation.

Importantly, the above scenario entails a major financial risk for natural gas generators. The closure (or substantial reduction) of natural gas capacity appears not to be plausible due to the high financial costs that such investment decision involves. Thus, overcapacity of natural gas as triggered by the CM could lead put lead substantive financial compensation claims from gas plants operators, similarly to 
the situation experienced with the phase-out of nuclear power plants in Germany [45]. In this regard, a study from carbon tracker has estimated a financial risk of over $55 \%$ unneeded Capex for gas generation in Italy under the IEA 450 scenario in 2015 [46].

Furthermore, and more generally, the impacts of the $\mathrm{CM}$ and the phase-out of coal-fired power plants on consumer prices remain unclear [25]. Yet the de-carbonization and energy security objectives of the NECP as pursued by the CM are conditional upon the development of the related infrastructures, more specifically with regard to full integration of natural gas and electricity dispatch with isolated territories, such as the Sardinian and Sicily islands. Such costs, including those related to grid extension for RES generation, are to be borne by transmission and distribution system operators, and therefore to be passed on to consumers.

With regard to the uptake of RES generation, the newly enacted auctions for RES projects have witnessed a lower participation then expected, albeit all capacity has been ultimately allocated. The auctions as main support scheme for RES should however be gradually replaced by other, genuine market-oriented instruments, such as PPAs, in order to ensure full market parity of RES. According to the Italian NECP, PPAs are expected to contribute to at least 0.5 TWh additional RES power each year. As Section 4 has demonstrated, despite the new regulatory setup introduced in 2019 through the RES Decree, PPAs market has clearly fallen short in delivering on such ambition, in total contributing to $600 \mathrm{MW}$, equalling approximately $1.5 \%$ of the expected RES capacity [34]. Even assuming a continuous uprising trend in development of wind and solar generation, a $23 \mathrm{GW}$ and $3.5 \mathrm{GW}$ of installed capacity gap remains with regard to the NECP targets for solar and wind, respectively (see Figures 10 and 11) [34].

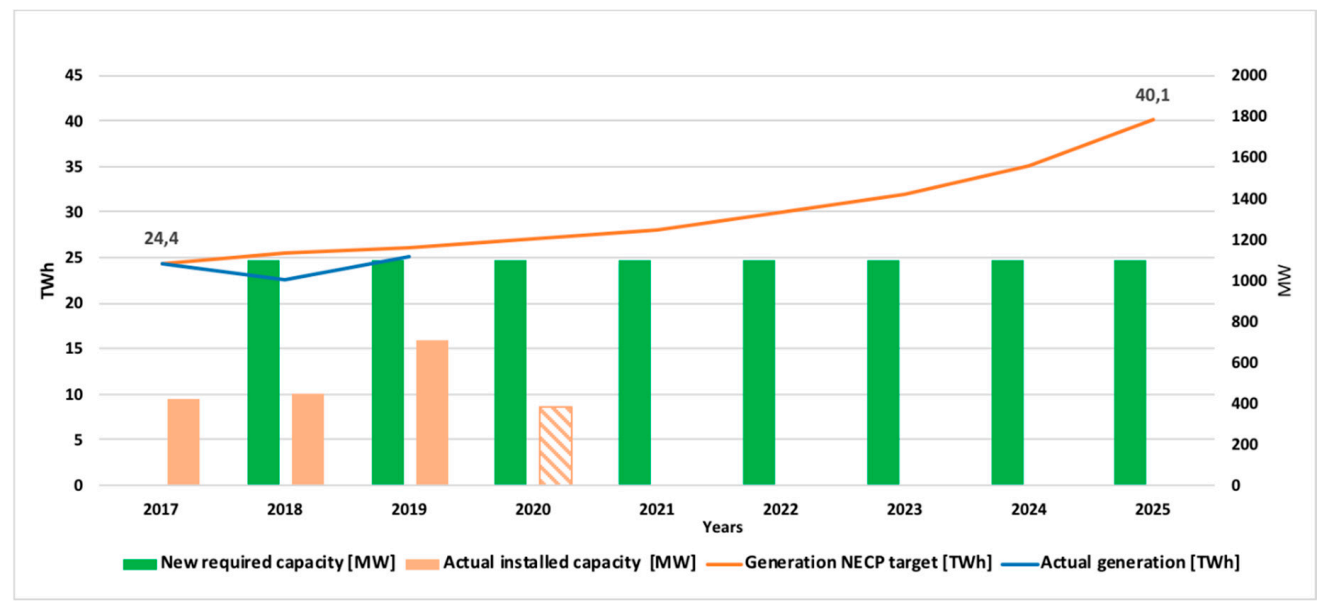

Figure 10. Solar generation capacity trajectories under NECP scenario and current trends [34].

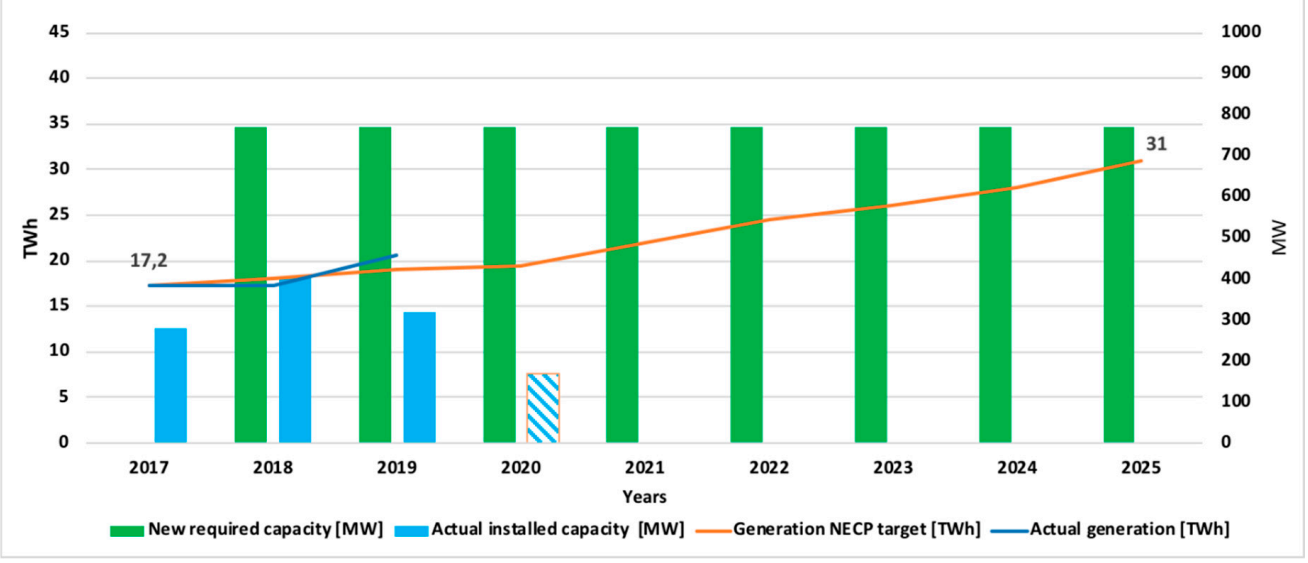

Figure 11. Wind generation capacity trajectories under NECP scenario and current trends [34]. 
In this regard, a major regulatory bottleneck is to be identified in the permitting procedures for both key energy infrastructures and RES large-scale projects, which are undermined by poor coordination, unclear allocation of competences, and lack of adequate financial resources and expertise for public authorities at the sub-national (i.e., Regional and local) level. As a prospective outlook, it must be noted that the recent COVID-19 outbreak has resulted in an abrupt roadblock to the on-going permitting procedures needed to duly implement Italian NECP's roadmap on de-carbonization of the energy sector. Such stagnation in turn spurred a swift response by the Italian legislator towards a substantial streamlining of permitting procedures for strategic energy infrastructures, thus arguably overcoming considerable administrative barriers for projects and infrastructures developers. The actual effectiveness of such new measures, however, remains to be seen and appraised. Hence while Italy is arguably acquiring a front-runner role in the transition away from coal-fired generation in the EU (and hopefully drive similar undertakings elsewhere), several technical and legal obstacles remain in the way to the achievement of such ambitious path in the near future.

Author Contributions: Conceptualization, M.F.; Data curation, P.B., C.C. and P.C.; Formal analysis, P.B. and A.F.; Funding acquisition, P.B.; Methodology, A.F. and M.F.; Supervision, P.B., C.C. and P.C.; Writing-original draft, M.F. All authors have read and agreed to the published version of the manuscript.

Funding: This research received no external funding.

Acknowledgments: We wish to thank the unknown reviewers for the valuable and insightful comments and suggestions.

Conflicts of Interest: The authors declare no conflict of interest.

\section{References}

1. European Commission. Communication, COM/2018/773 Final, a Clean Planet for All. A European Strategic Long-Term Vision for a Prosperous, Modern, Competitive and Climate Neutral Economy; European Commission: Brussels, Belgium, 2018.

2. Caldecott, B.; Tulloch, D.J.; Bouveret, G.; Pfeiffer, A.; Kruitwagen, L.; McDaniels, J.; Dericks, G. The fate of european coal-fired power stations planned in the Mid-2000s: Insights for policymakers, companies, and investors considering new coal. Ssrn Electron. J. 2017. [CrossRef]

3. Heinrichs, H.U.; Schumann, D.; Vögele, S.; Biß, K.H.; Shamon, H.; Markewitz, P.; Többen, J.; Gillessen, B.; Gotzens, F.; Ernst, A. Integrated assessment of a phase-out of coal-fired power plants in Germany. Energy 2017, 126, 285-305. [CrossRef]

4. European Environmental Agency. Greening the Power Sector: Benefits of an Ambitious Implementation of Europe's Environment and Climate Policies, Briefing no. 18/2018. Available online: https://www.eea.europa. $\mathrm{eu} /$ themes/industry/industrial-pollution-in-europe/benefits-of-an-ambitious-implementation (accessed on 31 July 2020).

5. King, L.C.; van der Bergh, J.C. Implications of net energy-return-on-investment for a low-carbon energy transition. Nat. Energy 2018, 3, 334-340. [CrossRef]

6. European Commission. Communication, COM (2020) 564 Final, an EU-Wide Assessment of National Energy and Climate Plans; European Commission: Brussels, Belgium, 2020.

7. Farfan, J.; Breyer, C. Structural changes of global power generation capacity towards sustainability and the risk of stranded investments supported by a sustainability indicator. J. Clean. Prod. 2017, 141, 370-384. [CrossRef]

8. Italian Integrated National Energy and Climate Plan. Available online: https:/ec.europa.eu/energy/sites/ ener/files/documents/it_final_necp_main_en.pdf (accessed on 2 August 2020).

9. RSE. Decarbonizzazione Dell'economia Italiana: Scenari di Sviluppo del Sistema Energetico Nazionale. Available online: https:/www.minambiente.it/sites/default/files/archivio/allegati/rse_decarbonizzazione_ web.pdf (accessed on 24 July 2020).

10. Kittel, M.; Goeke, L.; Kemfert, C.; Oei, P.Y.; von Hirschhausen, C. Scenarios for coal-exit in Germany-A model-based analysis and implications in the European context. Energies 2020, 13, 2041. [CrossRef]

11. Rentier, G.; Lelieveldt, H.; Kramer, G.J. Varieties of coal-fired power phase-out across Europe. Energy Policy 2019, 132, 620-632. [CrossRef] 
12. SDSN-IDDRI. Deep Decarbonization Pathways Project, Pathways to Deep Decarbonization 2015 Report. Available online: https:/www.iddri.org/en/publications-and-events/report/pathways-deep-decarbonization2015-report-executive-summary (accessed on 18 August 2020).

13. Bellantuono, G. Legal pathways of decarbonisation in the EU: The case of coal phase-out. Oil Gas. Energy Law 2019, 17, 1-24. Available online: www.ogel.org/article.asp?key=3830 (accessed on 20 July 2020). [CrossRef]

14. International Energy Agency, Country Profile: Italy. Available online: https://www.iea.org/countries/italy (accessed on 20 September 2020).

15. Website of Italian Ministry of Environment, Land and Sea, Environmental Assessments and Permits Portal (AIA-SEA-EIA). Available online: https://va.minambiente.it/it-IT (accessed on 6 August 2020).

16. Alved Dias, P.; Kanellopoulus, K.; Mederac, H.; Kapetaki, Z.; Miranda-Barbosa, E.; Shortall, R.; Czako, V.; Telsnig, T.; Vasquez-Hernandez, C.; Lacal Arantegui, R.; et al. EU Coal Regions: Opportunities and Challenges Ahead, EUR 29292 EN.; Publications Office of the European Union: Luxembourg, 2018. [CrossRef]

17. ISPRA. National Inventory Report 2020. Available online: http://www.sinanet.isprambiente.it/it/sia-ispra/ serie-storiche-emissioni/national-inventory-report/view (accessed on 5 August 2020).

18. Ministry of Economic Development and Ministry of Environment, Land and Sea. Strategia Energetica Nazionale. 2017. Available online: https://www.mise.gov.it/images/stories/documenti/Testo-integrale-SEN2017.pdf (accessed on 31 July 2020).

19. Terna S.P.A. Rapporto Adeguatezza Italia 2019. Available online: https://download.terna.it/terna/Rapporto\% 20Adeguatezza\%20Italia\%202019_8d71cb7ff32ad37.pdf (accessed on 5 August 2020).

20. ENTSO-E. Mid-Term Adequacy Forecast. 2019 Edition, Appendix 1; ENTSO-E: Brussels, Belgium. Available online: https://eepublicdownloads.entsoe.eu/clean-documents/sdc-documents/MAF/2019/MAF\%202019\% 20Appendix\%201\%20-\%20Detailed\%20Results\%2C\%20Sensitivities\%20and\%20Input\%20Data.pdf (accessed on 2 August 2020).

21. SNAM; Terna S.P.A. La Transizione Energetica in Italia e il Ruolo del Settore Elettrico e del Gas. 2019. Available online: https://download.terna.it/terna/Transizione_Energetica_8d75215ad40fffa.pdf (accessed on 5 August 2020).

22. Terna S.P.A. Mercato Della Capacità-Rendiconto degli Esiti Asta Madre. 2022. Available online: https://download.terna.it/terna/2019_12_06_Rendiconto\%20EsitiAsta\%202022_PUBBLICATO_ 8d7c06cc9f8470b.pdf (accessed on 30 July 2020).

23. Terna S.P.A. Mercato Della Capacità-Rendiconto Degli Esiti Asta Madre. 2023. Available online: https: //download.terna.it/terna/Rendiconto\%20EsitiAsta\%202023_8d78adbacbbe508.pdf (accessed on 30 July 2020).

24. International Energy Agency. World Energy Outlook 2019; IEA: Paris, France, 2020; p. 270.

25. European Commission. Staff Working Document, SWD (2020) 911 Final, Assessment of the Final National and Energy Climate Plan of Italy; European Commission: Brussels, Belgium, 2020.

26. ACER. Capacity Remuneration Mechanisms and the Internal Market for Electricity; ACER: Ljubljana, Slovenia, 2013.

27. ISPRA. Fattori di Emissione Atmosferica di Gas a Effetto Serra nel Settore Elettrico Nazionale e Nei Principali Paesi Europei, Edizione 2020. Available online: https://www.isprambiente.gov.it/files2020/pubblicazioni/ rapporti/Rapporto317_2020.pdf (accessed on 24 July 2020).

28. European Commission. Staff Working Document, SWD (2013) 438 Final, Generation Adequacy in the Internal Electricity Market_Guidance on Public Interventions; European Commission: Brussels, Belgium, 2013; p. 3.

29. Pototschnig, A.; Godfried, M. Capacity Mechanisms and the EU Internal Electricity Market. The Regulators' View; ACER: Ljubljana, Slovenia, 2013.

30. Meulman, L.; Méray, N. Capacity Mechanisms in Northwest Europe. Between a Rock and a Hard Place. Clingendael International Energy Programme; Nederlands Institut voor Internationale Betrekkingen: The Hague, The Netherlands, 2012.

31. European Commission. Report COM (2016) 752 Final, Final Report of the Sector Inquiry on Capacity Mechanisms; European Commission: Brussels, Belgium, 2016.

32. Gestore dei Servizi Energetici (GSE). Sintesi Rapporto Delle Attività. 2019. Available online: https: //www.gse.it/documenti_site/Documenti\%20GSE/Rapporti\%20delle\%20attività/RA2019.pdf (accessed on 2 August 2020).

33. Bruck, M.; Sandborn, P.; Goudarzi, N. A levelized cost of energy (LCOE) model for wind farms that include power purchase agreements (PPAs). Renew. Energy 2018, 122, 131-139. [CrossRef]

34. Energy Strategies Group. Renewable Energy Report 2020; Politecnico di Milano: Milan, Italy, 2020. 
35. Bloomberg NEF. New Energy Outlook 2020; Bloomberg NEF: New York, NY, USA, 2020.

36. PPA Committee. Final Report 2019; PPA Committee: Milan, Italy, 2020.

37. Cafaro, C.; Ceci, P.; Fardelli, A.; Zazzu, E. La trasformazione del settore energetico in Italia. Ing. Ambiente 2020, 7, 1-13.

38. Maestroni, A. La questione della localizzazione di impianti di produzione di energie rinnovabili a valle delle linee guida ministeriali. Corte costituzionale e Corte di giustizia arbitri tra esigenze di tutela paesistica e di sviluppo economico. Riv. Giuridica Ambiente 2012, 5, 569.

39. Gestore dei Servizi Energetici (GSE). Regolazione Regionale: Generazione Elettrica da Fonti Rinnovabili. 2018. Available online: http://enerweb.casaccia.enea.it/enearegioni/UserFiles/Regolazione_regionale_2018.pdf (accessed on 20 July 2020).

40. Braaksma, L.; Fleming, R. Phasing out coal-fired power plants in the European Union: Examples from the Netherlands and Germany. In European Energy Law Report; Roggenkamp, M.M., Banet, C., Eds.; Intersentia: Cambridge, UK, 2020; Volume 13, pp. 261-288.

41. European Commission. Document C (2018) 617 Final, State Aid SA.42011 (2017/N)-Italy-Italian Capacity Mechanism; European Commission: Brussels, Belgium, 2018.

42. Spees, K.; Newell, S.A.; Pfeifenberger, J.P. Capacity markets-Lessons learned from the first decade. Econ. Energy Env. Policy 2013, 2, 1-26. [CrossRef]

43. Gonzalez-Diaz, F.E. EU Policy on capacity mechanisms. In Capacity Mechanisms in the EU Energy Market: Law, Policy and Economics; Hancher, L., de Hauteclocque, A., Sadowska, M., Eds.; OUP: Oxford, UK, 2015.

44. Mastropietro, P.; Fontini, F.; Rodilla, P.; Batlle, C. The Italian capacity remuneration mechanism: Critical review and open questions. Energy Policy 2018, 123, 659-669. [CrossRef]

45. Ludwigs, M. Germany's nuclear phase out and the right to property. Eur. Netw. Law Regul. Q. 2016, 1, 44.

46. Carbon Tracker Initiative. The \$2 Trillion Stranded Assets Danger Zone: How Fossil Fuels Firms Risk Destroying Investor Returns, London, United Kingdom. Available online: www.carbontracker.org/wpcontent/uploads/2015/11/CAR3817_Synthesis_Report_24.11.15_WEB2.pdf (accessed on 13 October 2020).

Publisher's Note: MDPI stays neutral with regard to jurisdictional claims in published maps and institutional affiliations.

(C) 2020 by the authors. Licensee MDPI, Basel, Switzerland. This article is an open access article distributed under the terms and conditions of the Creative Commons Attribution (CC BY) license (http://creativecommons.org/licenses/by/4.0/). 